\title{
Constraints on schwa apocope in Middle High German
}

Renate Raffelsiefen

\section{Introduction}

When described as a deletion rule, word-final schwa loss in Middle High German (MHG) is highly idiosyncratic. Systematic restrictions on preceding segments indicate phonological conditioning of the rule. Yet a phonological motivation is elusive. The impression of arbitrariness is reinforced by the observation that specific phonological restrictions correlate with morphological and even semantic properties of words. For instance, why did schwa disappear only after liquids in feminine count nouns but also after nasals and voiceless obstruents in most unpluralizable nouns? Why are the phonological conditions for schwa loss in unpluralizable nouns identical to those in uninflected adjectives? Why do the conditions for schwa loss in titles or swear words differ from those in other nouns?

The answers to these questions proposed in this paper are based on constraints rather than on rules (cf. Prince and Smolensky 1993) and rely on two assumptions. First, we assume a constraint *SCHWA implying that all schwas will disappear unless needed to satisfy a higherranking constraint. In this approach the true generalizations which determine the development of schwas concern the conditions for stability rather than for loss. The second assumption is that there exists a constraint which requires all members of an inflectional paradigm to be identical in certain respects. This constraint, which will be referred to as LEVEL, presupposes that the forms to be evaluated consist of entire paradigms rather than individual words.

Together these two assumptions allow for a description of word-final schwa loss in MHG which refers neither to segment classes, nor to morphological or semantic word properties. The analysis is also relevant for the notion of possible language change.

The paper is structured as follows. In Section 2 I describe the strictly phonological stability conditions for final schwa, which apply in all words including those which are not members of a paradigm. In Sec- 
tion 3 it is shown that in words which belong to inflectional paradigms schwas are generally stable for as long as the paradigm includes at least one member which requires a schwa in the corresponding site for phonological reasons. The conclusions are summarized in Section 4.

\section{The Voice Stability Effect}

In some classes of words schwas disappeared after sonorants and voiceless obstruents, but remained after voiced obstruents. Compare for instance the MHG collective neuter nouns in (1a) with those in (1b), where the final schwa was preceded by a voiced obstruent and remained. The circumflex indicates vowel length in MHG orthography. The glosses refer to the MHG meanings. ${ }^{1}$ The abbreviation NHG stands for 'New High German' and refers to the present day language. Schwas in MHG result from the historical reduction of full vowels in unstressed position, which marked the transition from OHG to MHG (e.g. OHG ápful > MHG ápf[ə]l 'apple', OHG hérbist > MHG hérb[ə] st 'harvest', OHG mélo > MHG mél[ə]] 'flour'):

(1)

a.
MHG NHG

gemüet[ə] Gemiit geschirr[ə] Geschirr geblüet[ə] Geblüt gebüsch[ə] Gebüsch gewülk[ə] Gewölk gestein[ə] Gestein gestirn[ə] Gestirn

b. gemüe[z][ə] getreid[ə] gesind[ə] gewerb[ə] gelend[ə] gebirg[ə] gesmîd[ə]

\section{Gemü[z][ə]} Getreid[ə] Gesind[ə] Gewerb[ə] Geländ[ə] Gebirg[ə] Geschmeid[ə]

'mind'
'dishes'
'blood'
'bushes'
'clouds'
'rocks'
'stars'
'mush'
'food'
'servants'
'business'
'terrain'
'mountains'
'wrought iron'

'mind' 'dishes' 'blood' 'bushes' 'clocks' 'stars' 'mush' 'servants' 'business' 'terrain' 'wrought iron'

The development of the final schwa in the 88 MHG collective neuter nouns derived by circumfixation (i.e. geXe) which still exist in NHG is shown in (2): ${ }^{2}$ 
(2)

Total Schwa retained Schwa lost in MHG in NHG in NHG

Final schwa after

64

voiceless obstruents or sonorants:

Final schwa after

2

62

(Gerippe, Gefälle)

voiced obstruents:

The same phonological restriction on schwa deletion is found in uninflected adjectives as illustrated in (3). ${ }^{3}$

(3) $\mathrm{MHG}$ NHG

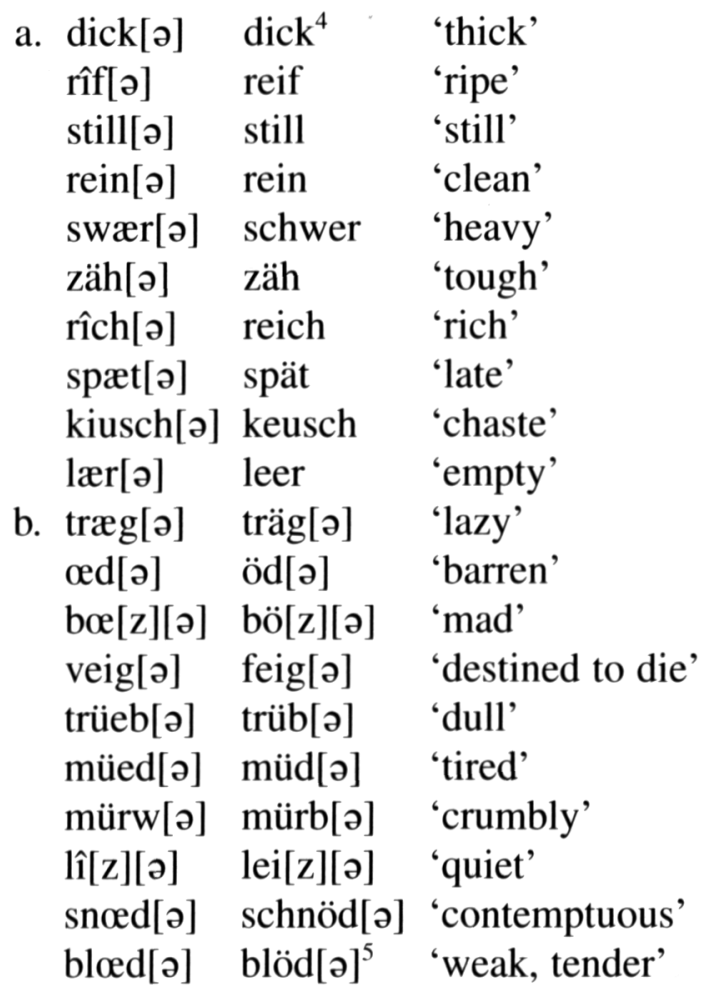

Of the list of $87 \mathrm{MHG}$ adjectives ending in schwa (i.e. the former $j a-/ j \hat{o}-$ stems) listed in Paul, 58 still exist (cf. Paul et al. 1989: 212). ${ }^{6}$ (4) shows the distribution of word-final schwa for those adjectives in NHG: 


\begin{tabular}{llll} 
& $\begin{array}{l}\text { Total } \\
\text { in MHG }\end{array}$ & $\begin{array}{l}\text { Schwa retained } \\
\text { in NHG }\end{array}$ & $\begin{array}{l}\text { Schwa lost } \\
\text { in NHG }\end{array}$ \\
\hline $\begin{array}{l}\text { Final schwa after } \\
\text { voiceless obstruents } \\
\text { or sonorants: }\end{array}$ & 43 & $\begin{array}{c}1 \\
(\text { irre })\end{array}$ & 42 \\
$\begin{array}{l}\text { Final schwa after } \\
\text { voiced obstruents: }\end{array}$ & 15 & 12 & $\begin{array}{c}\text { (wild, elend, } \\
\text { fremd) }\end{array}$
\end{tabular}

The near-complete loss of word-final schwas after voiceless obstruents or sonorants is a rather recent development. Wilmanns (1911) notes that the adjectives nütze 'useful', irre 'mad', dürre 'dry', stille 'still', dünne 'thin', and zähe 'tough' 'can or must retain the final schwa'. 'Of these words, the last four are no longer pronounced with final schwa. The three adjectives listed in (4) which exceptionally lost the schwa will be discussed shortly.

Viewed in terms of conditions on deletion the pattern of schwa loss illustrated above is described by (5). The additional morphological restrictions stated in that rule are discussed in Section 3:

$$
\left[\text { ə] } \rightarrow \varnothing /\left\{\begin{array}{l}
{[+ \text { son }]} \\
{[- \text { son] }} \\
{[- \text { voice }]}
\end{array}\right)\right\} \# \begin{aligned}
& \text { Domain: strong non-count nouns } \\
& \text { (including collective neuter nouns, } \\
& \text { cf. (1)), uninflected adjectives (cf. } \\
& (3)), \text { titles, swear words }
\end{aligned}
$$

Rule (5) is phonologically odd because sonorants and voiceless obstruents do not constitute a natural class. This problem disappears if the conditions for schwa stability are described instead: schwas are stable after voiced obstruents and delete elsewhere. According to Wilmanns (1911: 364) the deletion patterns in (5) have historically been related to the absence of voiced obstruents in syllable-final position in German (cf. Adelung 1781). The constraint in question can be formulated as follows (cf. Shibatani 1973):

(6) Coda Voice (preliminary version)

Voiced obstruents in coda position are prohibited. 
Reference to a specific class of speech sounds can be avoided by invoking the notion of markedness as in constraint (7). This constraint presupposes that the unmarked value for the feature [ \pm voice] is plus for sonorants and minus for obstruents (cf. Chomsky and Halle 1968: 406):

(7) Coda Voice (final version)

Speech sounds in coda position must be unmarked for the feature [ \pm voice].

The deletion patterns illustrated in (1) and (3) can be described by ranking CODA VoICE above a general constraint against schwas. ${ }^{8} \mathrm{~A}$ preliminary version of the latter constraint is stated in (8) (cf. Mester and Ito 1994):

(8) *SCHWA

Schwas are prohibited.

Evaluation of candidate forms with respect to $* \mathrm{SCHWA}$, which expresses the markedness of schwas, is demonstrated with the example MHG er[ə]z[ə], NHG Erz 'ore' shown in tableau (9): ${ }^{9}$

\begin{tabular}{|c|c|c|}
\hline (9) & & *SCHWA \\
\hline & er[ə]z[ə] & $* *$ \\
\hline & $\operatorname{er}[\partial] z$ & $*$ \\
\hline & erz[ə] & $*$ \\
\hline 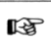 & erz & \\
\hline
\end{tabular}

Tableau (10), which compares forms with schwa with the corresponding schwaless forms, shows that the ranking CODA VoICE $\gg *$ SCHWA accounts for the data considered so far. The examples in $(10 \mathrm{a}-\mathrm{c})$ represent words in which the final schwa is preceded by a voiceless obstruent, a sonorant, and a voiced obstruent, respectively. The exclamation mark indicates a "fatal" violation, which leads to the elimination of the candidate. 


\begin{tabular}{|c|c|c|c|}
\hline (10) & Candidates & CODA VoICE & *SCHWA \\
\hline \multirow[t]{2}{*}{ a. } & \multirow{2}{*}{$\begin{array}{l}\operatorname{dick}[\partial] \\
\text { dick }\end{array}$} & & $* !$ \\
\hline & & & \\
\hline \multirow[t]{2}{*}{ b. } & \multirow{2}{*}{$\begin{array}{l}\text { rein[ə] } \\
\text { rein }\end{array}$} & & $* !$ \\
\hline & & & \\
\hline \multirow[t]{2}{*}{ c. } & \multirow{2}{*}{$\begin{array}{l}\text { træg } \\
\text { træg[ə] }\end{array}$} & $* !$ & \\
\hline & & & $*$ \\
\hline
\end{tabular}

The fact that Coda Voice is never violated in German has led proponents of rule-based approaches to conclude that there is an automatic rule of Final Devoicing in German. The observation that the final schwa in words like trag [ə] has been stabilized by the illformedness of the form $\operatorname{trc}[g]$ argues against the existence of such a rule. Yet the question arises of what rules out the "devoiced" candidate trak. This candidate cannot be eliminated on phonological grounds but rather calls for a different type of constraint which relates candidates to input forms. Ranking the constraint Preserve Voice stated in (11) higher than *SCHWA yields the desired effect: ${ }^{10}$

\section{(11) Preserve Voice \\ The feature [ \pm voice] must be preserved}

Tableau (12) shows how the ranking of the three constraints considered so far accounts for the preference of schwaless forms unless the schwa is preceded by a voiced obstruent. ${ }^{11}$ 


\begin{tabular}{|c|c|c|c|c|c|}
\hline (12) & Input & Candidates & 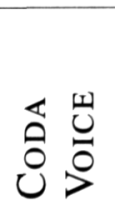 & 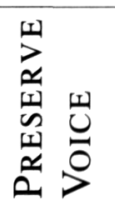 & 胥 \\
\hline \multirow[t]{2}{*}{ a. } & \multirow{2}{*}{$\operatorname{dick}[ə]$} & dick[ə] & & & $* !$ \\
\hline & & dick & & & \\
\hline \multirow[t]{2}{*}{ b. } & \multirow{2}{*}{$\operatorname{rein}[ə]$} & rein[ə] & & & $* !$ \\
\hline & & rein & & & \\
\hline \multirow[t]{3}{*}{ c. } & \multirow{3}{*}{$\operatorname{træg}[ə]$} & træg & $* !$ & $8 \pi$ & 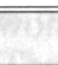 \\
\hline & & træk & & $* !$ & 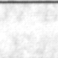 \\
\hline & & træg[ə] & & & $*$ \\
\hline
\end{tabular}

All input forms in (12) end in schwa to match the historical starting point of schwa deletion. Specifically, the input forms in (12) represent the surface forms which were historically encountered in language acquisition. The constraint ranking accounts for the forms selected by learners on the basis of those input forms, which then surfaced in their own speech (i.e. the forms dick, rein, and trag [ə] in (12)). "Schwa deletion" thus refers to an era when learners were more likely to encounter words ending in schwa than to render that schwa in their own speech with the result that input forms like dick[a] and rein[ə] were eventually replaced by the restructured forms dick and rein

The constraint CODA VoICE has been inviolable in German since MHG, when all voiced obstruents in coda position were devoiced (cf. Old High German tou[b] 'mindless' > MHG tou[p], OHG ar $[g]$ 'bad'> MHG $\operatorname{ar}[k])$. The transition from OHG to MHG is thus marked by a constraint reordering whereby CODA VoICE came to dominate Preserve Voice. Synchronically, the continuous high ranking of Coda Voice w.r.t. Preserve Voice is manifested in the absence of analogical restoration of voiced obstruents in coda position ${ }^{12}$ and in conditions on loan word adoption: voiced obstruents in coda position are replaced by the corresponding voiceless obstruents when loan words are adopted into German (e.g. Swedish smörgåsbor [d] 'buffet' > German Smörgåsbor $[t]$, French vo[g] 'vogue' > German Vo[k]). It appears then that while existing schwas (i.e. schwas which result from the 
historical reduction of full vowels in unstressed position, which marked the transition from OHG to MHG) have been stable to satisfy the constraints Coda VoICe and Preserve Voice, no schwas have been inserted to satisfy those constraints. That is, existing schwas have been stable to ensure the continuous syllabification of voiced obstruents in onset position but no new schwas have been inserted to yield such a syllabification (e.g. OHG tou[b] became MHG tou $[p]$ rather than *tou. [ba]). This shows that Preserve Voice dominates *SCHWA and is dominated by a constraint against vowel epenthesis. ${ }^{13}$

Consider now the words in (4) in which schwa deleted despite being preceded by a voiced obstruent. The adjectives elend and fremd differ from the other adjectives under consideration in that they consisted of a ternary foot in MHG (i.e. MHG éllènde, vrémede) provided that a foot consists of a stressed syllable and the following less stressed syllables within the phonological word. ${ }^{14}$ The tendency in German not to exceed binary feet was already observed by Heyse (1838). His observation can be stated in terms of the following constraint: ${ }^{15}$

\section{(13) $\left(\sigma^{2}\right)_{\mathrm{F}}$}

Feet must be maximally binary.

The fact that schwa systematically deleted after voiced obstruents in words consisting of ternary feet indicates that the constraint $\left(\sigma^{2}\right)_{\mathrm{F}}$ dominates Preserve Voice. Recall that *CodA Voice is never violated in MHG and NHG:

\begin{tabular}{|c|c|c|c|c|c|}
\hline Input & Candidates & $\begin{array}{l}\overleftrightarrow{0} \\
0 \\
0 \\
0\end{array}$ & $\left(\sigma^{2}\right)_{\mathrm{F}}$ & 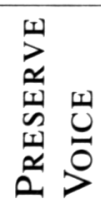 & 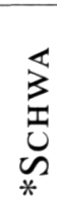 \\
\hline \multirow{3}{*}{ éllènd[ə] } & éllènd & $* !$ & & & \\
\hline & éllènd[ə] & & $* !$ & & \\
\hline & éllènt & & & $*$ & \\
\hline
\end{tabular}

The constraint ranking in tableau (14) also accounts for the different development of the final schwa in the words in (15a) and (15b), which 
have similar segmental structure but differ with respect to foot structure:

\section{MHG NHG}

a. gégende Gégen[t] 'area' lébende lében[t] 'alive'

b. legénde Legénd[ə] 'legend' behénde behénd[ə] 'swift'

Most cases where schwa deleted after voiced obstruents can be explained with reference to foot binarity. The question of why schwa disappeared in MHG wilde (NHG wild) is less clear. The loss appears to be phonologically motivated as the Voice Stability Effect generally fails after the cluster $l d$.

The constraint ranking in tableau (14) applies to all phonological words in MHG regardless of their category. ${ }^{16}$ However the effect is visible only in words which do not belong to inflectional paradigms. This is because in inflected words certain schwas are stabilized by independent constraints on paradigmatic leveling which obscure the Voice Stability Effect. In Section 3 it will be shown that restricting schwa deletion to specific morphological categories as in rule (5) becomes unnecessary if candidates consist of entire inflectional paradigms rather than individual words.

Consider next the issue of possible deletion rules, or rather, of possible stability effects. Three hypothetical stability effects are listed in (16):

Schwa is stable:

Schwa deletes:

$\checkmark \mathrm{A}$ after voiced obstruents elsewhere

*B after voiceless obstruents elsewhere

*C after sonorants elsewhere

Type A corresponds to the Voice Stability Effect discussed above. This stability effect implies that $*$ SCHWA is dominated by a constraint against voiced obstruents in syllable codas. Since there is strong evidence both from language acquisition (cf. Stampe 1969; Smith 1973) and cross-linguistically that such a constraint exists pattern A qualifies as a possible stability effect. 
In contrast, pattern $\mathrm{B}$ presupposes a constraint against voiceless obstruents in coda position and pattern $\mathrm{C}$ presupposes a constraint against sonorants in coda position. Without independent evidence for either constraint the corresponding stability effects can be ruled out. Given the range of (presumably universal) constraints it is accordingly possible to predict the range of possible stability effects. ${ }^{17}$ The theory thus allows one to assess the plausibility of linguistic descriptions. For example, consider Koziol's (1937: 308) description of schwa loss in Middle English: "The loss within each individual category-weakly stressed, polysyllabic, disyllabic, native and borrowed words, begins earlier after voiceless stops and fricatives, as well as after liquids or nasals than after voiced stops or fricatives". Minkova (1991: 111) dismisses Koziol's observation on phonological grounds: "It would be even more than difficult to find the common denominator in the environment defined by Koziol, so the whole proposal seems at best indefensible". Minkova errs in assessing Koziol's observations in terms of a deletion rule. Viewed from the 'stability' perspective the pattern of Middle English schwa loss observed by Koziol is simply another instance of the Voice Stability Effect. ${ }^{18}$

\section{LeVEL Stability Effects}

\subsection{Schwa loss in verbs}

Consider the type of quantity sensitivity exhibited by schwa apocope in the MHG first person singular present tense forms in (17). While the final schwa in these forms is generally considered an inflectional morpheme in NHG the data in (17) show that its stability is phonologically governed in MHG: schwa never disappeared if preceded by either a long stem vowel (including diphthongs) or a long consonant. ${ }^{19}$ Recall that the circumflex indicates vowel length. Orthographic double segments indicate consonantal length. 
(17)

$\begin{array}{lll}\text { MHG } & \text { NHG } & \\ \text { a. } \text { mal[ə] > mal } & \text { mahle } & \text { '(I) grind' } \\ \text { var[ə] > var } & \text { fahre } & \text { '(I) go' } \\ \text { hol[ə] > hol } & \text { hole } & \text { '(I) call' } \\ \text { spil[ə] > spil } & \text { spiele } & \text { '(I) play' } \\ \text { ner[ə] > ner } & \text { nähre } & \text { '(I) cure' } \\ \text { stel[ə] > stel } & \text { stehle } & \text { '(I) steal' } \\ \text { hel[ə] > hel } & \text { hehle } & \text { '(I) conceal' } \\ \text { ber[ə] > ber } & \text { gebäre } & \text { '(I) bear' } \\ \text { scher[ə] > scher } & \text { schere } & \text { '(I) shear' } \\ \text { swer[ə] > swer } & \text { schwöre '(I) swear' } \\ \text { zer[ə] > zer } & \text { zehre } & \text { '(I) tear' } \\ \text { b. } \text { mâl[ə] } & \text { male } & \text { '(I) mark' } \\ \text { harr[ə] } & \text { harre } & \text { '(I) await' } \\ \text { teil[ə] } & \text { teile } & \text { '(I) share' } \\ \text { vall[ə] } & \text { falle } & \text { '(I) fall' } \\ \text { hœr[ə] } & \text { höre } & \text { '(I) hear' } \\ \text { küel[ə] } & \text { kühle } & \text { '(I) cool' } \\ \text { vüel[ə] } & \text { fühle } & \text { '(I) feel' } \\ \text { wüel[ə] } & \text { wühle } & \text { '(I) roll' } \\ \text { heil[ə] } & \text { heile } & \text { '(I) cure' } \\ \text { still[ə] } & \text { stille } & \text { '(I) calm' } \\ \text { vüer[ə] } & \text { führe } & \text { '(I) move' } \\ & \end{array}$

Apocope tends to be restricted by minimality conditions on output forms. In Estonian, for example, final vowels delete in nominative forms unless the remaining stem is a single syllable consisting of a short vowel followed by a short consonant (cf. McCarthy and Prince 1986). Apocope is restricted in a similar fashion in Germanic (Prokosch 1939), Lardil (Wilkinson 1988), and Proto-Nordic (Riad 1992).

In view of this general tendency to avoid monosyllabic words with a VC-rhyme the pattern of MHG schwa deletion calls for an explanation. Specifically, final schwa deleted precisely in words with a short stem vowel followed by a single consonant as shown in (17a), but was stable elsewhere. Yet another phonological oddity is the segmental restriction on schwa loss illustrated in (17a): the rule applies only after liquids as is shown by the fact of schwa non-deletion in the words 
shown in (18). Verbs in which the final schwa is preceded by a voiced obstruent are omitted from consideration to rule out potential Voice Stability Effects.

\begin{tabular}{|c|c|c|}
\hline 8) $\mathrm{MHG}$ & NHG & \\
\hline wat[ə] & wate & '(I) go' \\
\hline $\operatorname{nick}[$ [อ] & nicke & '(I) bend' \\
\hline bet[ə] & bete & '(I) beg' \\
\hline nëm[ə] & nehme & '(I) take' \\
\hline $\operatorname{den}[\partial]$ & dehne & '(I) stretch' \\
\hline wasch[ə] & wasche & '(I) wash' \\
\hline $\operatorname{lach}[\partial]$ & lache & '(I) laugh' \\
\hline knet[o] & knete & '(I) knead' \\
\hline kom[ə] & komme & '(I) come' \\
\hline sprech[ə] & spreche & '(I) speak' \\
\hline
\end{tabular}

The patterns of schwa loss illustrated in (17) and (18) can be described in terms of the deletion rule (19) (cf. Paul et al. 1989: 81).

(19) $[ə] \rightarrow \varnothing / X V L \_Y$ Domain: finite verb forms, feminine and masculine count nouns

To explain the deletion pattern in rule (19) within the constraint-based analysis proposed here, which presupposes a constraint against schwas, one must focus on the question of what stabilized the schwa in the examples in (17b) and (18). I will argue that the key to understanding the development of the final schwas in those words is the observation that they belong to inflectional paradigms and that the schwa deleted either in all members of a paradigm or in none. Consider the complete paradigms of MHG male '(I) grind', mâle '(I) mark', and mache '(I) make' listed in (20). Vowel alternations are typical for so-called strong verbs and do not affect the development of the final schwa in MHG. The grapheme $\langle\mathrm{ch}\rangle$ represents the velar fricative $[\mathrm{x}]$. 
(20)

$$
\begin{aligned}
& \text { SG } 1 \text {. a. } \operatorname{mal}[\partial]>\text { mal } \\
& \text { 2. mel[ə]st }>\text { melst } \\
& \text { 3. mel[ə]t }>\text { melt } \\
& \text { PL 1. mal[ə]n }>\text { maln } \\
& \text { 2. } \operatorname{mal}[ə] \mathrm{t}>\text { malt } \\
& \text { 3. mal[ə]nt }>\text { malnt }
\end{aligned}
$$

b. mâl[ə] mâl[ə]st mâl[ə]t mâl[ə]n mâl[ə]t mâl[ə]nt c. $\operatorname{mach}[\partial]$ mach[ə]st $\operatorname{mach}[ə] \mathrm{t}$ $\operatorname{mach}[$ [ə]n $\operatorname{mach}[$ ə]t mach[ə]nt

The claim that the schwa deleted either in all members of a paradigm or in none presupposes a definition of the paradigm in terms of agreement. Specifically, it is necessary to define a paradigm as the set of the inflected forms of a word whose distribution is determined solely by agreement with another element within the clause. On this definition the different verb forms in for instance (20a) are members of the same paradigm because their distribution is determined by agreement with the subject within the clause. In contrast, the inflected word forms in (21a), which relate to the same verb maln 'to grind', do not belong to a single paradigm because the choice of tense is not determined by agreement. Neither are the verb forms in (21b) members of a single paradigm because their distribution is determined not exclusively by agreement but also involve different tenses. The stability of the schwa in muol[ [ə] $t$ vis-à-vis schwa loss in $\operatorname{mal}([\partial])$ thus does not contradict the claim that schwa deleted in all members of a paradigm or in none, assuming that paradigms are defined in terms of agreement.
a. PL 1 mal([ə])n 'grind'
PL 1 muol[ə]n 'ground'
b. SG 1 mal([ə]) 'grind' PL 2 muol[ə]t 'ground'

Defining the paradigm is important because all and only the members of a paradigm are subject to a constraint LEVEL, which for the purpose of this paper will be defined as follows:

\section{(22) LEVEL}

All stem consonants must occupy the same syllable position in each member of a paradigm

The notion 'stem' in constraint (22) is used informally and describes the word without inflectional markers. ${ }^{20}$ For an illustration of LEVEL 
consider the evaluation of the three hypothetical paradigms in tableau (23), in which $n$ functions as an inflectional marker:

\begin{tabular}{|c|c|c|}
\hline \multicolumn{2}{|c|}{$(23)$} & \multirow[t]{2}{*}{ LEVEL } \\
\hline a. & {$\left[\begin{array}{l}\text { perl } \\
\text { perln }\end{array}\right]$} & \\
\hline b. & {$\left[\begin{array}{l}\text { per.le } \\
\text { per.len }\end{array}\right]$} & \\
\hline c. & {$\left[\begin{array}{l}\text { perl } \\
\text { per.len }\end{array}\right.$} & $*$ \\
\hline
\end{tabular}

The paradigm in (23a) satisfies LEVEL because the three stem consonants $p, r$, and $l$ occupy the same syllable position in each member. That is, the $p$ is always in head position and the two liquids are always in coda position. Paradigm (23b) satisfies LEVEL as well. Only paradigm (23c) violates LEVEL because the $l$ is in coda position in one member but in head position in another member.

The evaluation of the paradigms in tableau (23) may suggest that LEVEL could also be defined as a constraint requiring the number of syllables in each member to be the same. While such a definition would suffice to account for MHG verbal paradigms it would not always yield the desired result (cf. Section 3.4.). Specifically, the constraint LEVEL as defined in (22) expresses a preference for paradigms in which all members exhibit the same adjacency relations among the stem consonants (cf. (24a)) over a paradigm in which all members have the same number of syllables (cf. (24b)).

\begin{tabular}{|c|c|c|}
\hline$(2$ & & LEVEL \\
\hline a. & $\begin{array}{l}\text { perl } \\
\text { per.len }\end{array}$ & * \\
\hline b. & {$\left[\begin{array}{l}\text { pe.rel } \\
\text { per.len }\end{array}\right.$} & $* *$ \\
\hline
\end{tabular}

The fact that schwa deleted either in all members of a paradigm or in none indicates that the constraint LEVEL dominates *SCHWA. If stability of schwas rather than schwa deletion requires an explanation, the 
question arises of why the schwas failed to delete in certain paradigms. Arguably those paradigms include at least one member which requires a schwa for strictly phonological reasons. Consider first the question of why schwas failed to delete in inflected verbs after consonants other than liquids. Since the most sonorous inflectional suffix occurring in verbal paradigms is the nasal $n$, schwa loss would entail a sonority violation whenever the stem-final segment is less sonorous than liquids. The relevant constraint is based on the Head Law and the Coda Law proposed in Vennemann 1988 (cf. also Sievers 1901): ${ }^{21}$

\section{(25) Son}

A segment in the syllable head may only be followed by segments of higher sonority; a segment in the syllable coda may only be preceded by segments of higher sonority.

That is, for every segment in the syllable shell (i.e. head and coda) the sonority level must increase toward the nucleus. The sonority hierarchy is given in (26):

(26)

\begin{tabular}{llllll}
$\begin{array}{l}\text { Increasing } \\
\text { sonority }\end{array}$ & & $\begin{array}{r}\text { Decreasing } \\
\text { sonority }\end{array}$ & $\begin{array}{l}\text { Syllable } \\
\text { appendices: }\end{array}$ \\
\hline Vowel r & 1 & Nasal & Fricative Stop & s, t
\end{tabular}

The ranking among $r, l$, and the nasals in (26) is consistent with the 'discontinuous gradings' of sonority proposed by Sievers on auditory grounds (1901: 198f). ${ }^{22}$ According to (26) sonorants must precede obstruents in coda position and the only permissible sonorant clusters are $r l, r N, l N$, and $r l N(' \mathrm{~N}$ ' = nasal). Any other combinations result in 'sonority violations', which would inhibit schwa deletion as is shown in (27). The MHG words in each row differ only in the order of the consonants which flank the schwa.

\section{MHG NHG}

a. at[ə]m At[ə]m 'breath'

ov[ə]n Of[ə]n 'oven'

kell[ə]r Kell[ə]r 'cellar'

ham[ə]1 Hamm[ə]l 'wether'

ham[ə]r Hamm[ə]r 'hammer' 


\begin{tabular}{|c|c|c|}
\hline b. $\operatorname{zim}[\partial] \mathrm{t}$ & Zimt & 'cinnamon \\
\hline $\operatorname{sen}[\partial] f$ & Senf & 'mustard' \\
\hline quirr[ə]l & Quirl & 'whisk' \\
\hline hal[ə]m & Halm & 'stalk' \\
\hline har[ə]m & $\mathrm{Ha}$ & 'harm' \\
\hline
\end{tabular}

The development of the schwa in the words in (27) is determined by the fact that the clusters in (28a), but not those in (28b), violate SoN when occurring in coda position:

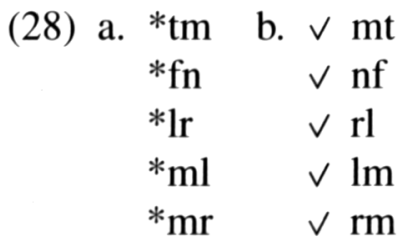

The observation that schwa never deletes if its loss would entail a SoN violation indicates that SoN dominates ${ }^{*}$ SCHWA as is shown in tableau (29). ${ }^{23}$ In fact, the constraint SoN is never violated in German. Tableau (29) merely compares forms with schwa with the corresponding schwaless candidates. To eliminate candidates like am, at, and alm it is necessary to rank various PRESERVE constraints higher than *SCHWA. ${ }^{24}$

\begin{tabular}{|ll|l||c|c|}
\hline (29) & Input & Candidates & SON & *SCHWA \\
\hline \hline a. & \multirow{2}{*}{ at[ə]m } & at[ə]m & & $*$ \\
\cline { 3 - 5 } & & atm & $* !$ & \\
\hline \hline b. & \multirow{2}{*}{ zim[ə]t } & zim[ə]t & & $* !$ \\
\cline { 3 - 5 } & & zimt & & \\
\hline
\end{tabular}

Consider next the syllable appendices listed in (26). Only coronal obstruents can be extrasyllabic in German. ${ }^{25}$ Schwa loss in the words in (30) accordingly does not violate Son since the final coronals are not part of the syllable proper.

(30) $\operatorname{mark}[$ ə]t $>$ markt 'market'; $\operatorname{ar}[\mathrm{ts}][$ əə]t $>\operatorname{ar}[\mathrm{ts}] \mathrm{t}$ 'medical doctor' 
Because $n$ is the most sonorous suffix occurring in verbal paradigms, schwas are never needed to prevent Son violations in paradigms with stem-final liquids as is illustrated with the paradigm of the verb $\operatorname{mal}([2]) n$ 'to grind' in (20). If the stem-final consonant is a nonliquid, schwas are needed to avoid Son violations in the first and third person plural forms, which include nasal suffixes (e.g. mach[ə]n $>*$ machn, mach[ə]nt $>*$ machnt $)$. The observation that the schwa is stable in all members of such paradigms (including mach[ə]) indicates that both SON and LEVEL dominate *SCHWA. To illustrate this analysis it suffices to represent the paradigms by listing distinct members only as shown in tableau (31). ${ }^{26}$ The constraint LEVEL is violated once in the second candidate in (31) because there is one stem consonant which appears in coda position in some members of the paradigm and in head position in others, i.e. the velar fricative represented by $\langle\mathrm{ch}\rangle$. ${ }^{*}$ ScHWA is violated five times in the third candidate listed because there are five occurrences of schwa.

\begin{tabular}{|l||c|c|c|}
\hline (31) & SoN & LEVEL & *SCHWA \\
\hline \hline$\left[\begin{array}{l}\text { mach } \\
\text { machst } \\
\text { macht } \\
\text { machn } \\
\text { machnt }\end{array}\right]$ & (*m! & & \\
\hline$\left[\begin{array}{l}\text { *machn, } \\
\text { mach } \\
\text { machst } \\
\text { mach[ə]n } \\
\text { mach[ə]nt }\end{array}\right]$ & & & \\
\hline$\left[\begin{array}{l}\text { mach[ə] } \\
\text { mach[ə]st } \\
\text { mach[ə]t } \\
\text { mach[ə]n } \\
\text { mach[ə]nt }\end{array}\right]$ & & $* !$ & \\
\hline
\end{tabular}

Consider now the second phonological restriction on schwa deletion 
expressed in rule (19), that is, the restriction concerning length. That restriction reflects the constraint WEIGHT stated in (32), which is based on the Weight Law proposed in Vennemann 1988:

\section{(32) WEIGHT}

The maximal weight of a stressed syllable is three moras.

Assuming that short vowels or single consonants consist of one mora and that long vowels, diphthongs, or geminate consonants consist of two moras the development of the schwa in the MHG infinitives shown in (33) can be described by ranking WeIGHT higher than *SCHWA.

a. mâl[ə]n *mâln 'to mark'
teil[ə]n *teiln 'to share'
vall[ə]n *valln 'to fall'
hœr[ə]n *hœrn 'to hear'
harr[ə]n *harrn 'to await'

b. mal[ə]n > maln 'to grind' hol[ə]n $>$ holn 'to call' spil[ə]n > spiln 'to play' ner[ə]n $>$ nern 'to cure' $\operatorname{var}[$ ə]n $>$ varn 'to go'

Tableau (34) gives an analysis of the historical schwa loss seen in (33b). Like Son, the constraint WeIGHT is never violated in MHG. Schwa loss in nouns like MHG ern[ə]st > ernst 'earnestness' does not violate WEIGHT because word-final coronal obstruents are extrasyllabic and hence do not contribute to syllable weight.

\begin{tabular}{|ll|l||l|c|}
\hline (34) & Input & Candidates & WEIGHT & *SCHWA \\
\hline \hline \multirow{2}{*}{ a. } & \multirow{2}{*}{ mâl[ə]n } & mâl[ə]n & & $*$ \\
\cline { 3 - 5 } & & mâln & $* !$ & \\
\hline b. & \multirow{2}{*}{ mal[ə]n } & mal[ə]n & & $* !$ \\
\cline { 3 - 5 } & & maln & & \\
\hline
\end{tabular}

Given the constraint ranking in (34) the MHG inflected verbs mal[a] '(I) grind' and mâl[ə] '(I) mark' differ in that the paradigm of mâl[ə] includes members in which the schwa is needed to avoid a WEIGHT violation (i.e. the forms $m a \hat{l}[$ [ə] $n$, mâl[ə] $n t$ ) whereas the paradigm of mal[ə] includes no such members. ${ }^{27}$ The members which require the schwa for phonological reasons are again the first and the third person 
plural, but in this case because the consonant $n$ (unlike $s$ or $t$ ) contributes to syllable weight. The observation that the schwa has been stable not only in the members which violate WEIGHT but in all members in the respective paradigms supports the claim that LEVEL dominates *Schwa. Tableau (35) accounts for the development of schwa in all inflected present tense verbs in MHG. Since both SoN and WeIGHT are inviolable in MHG they are not ranked with respect to each other.

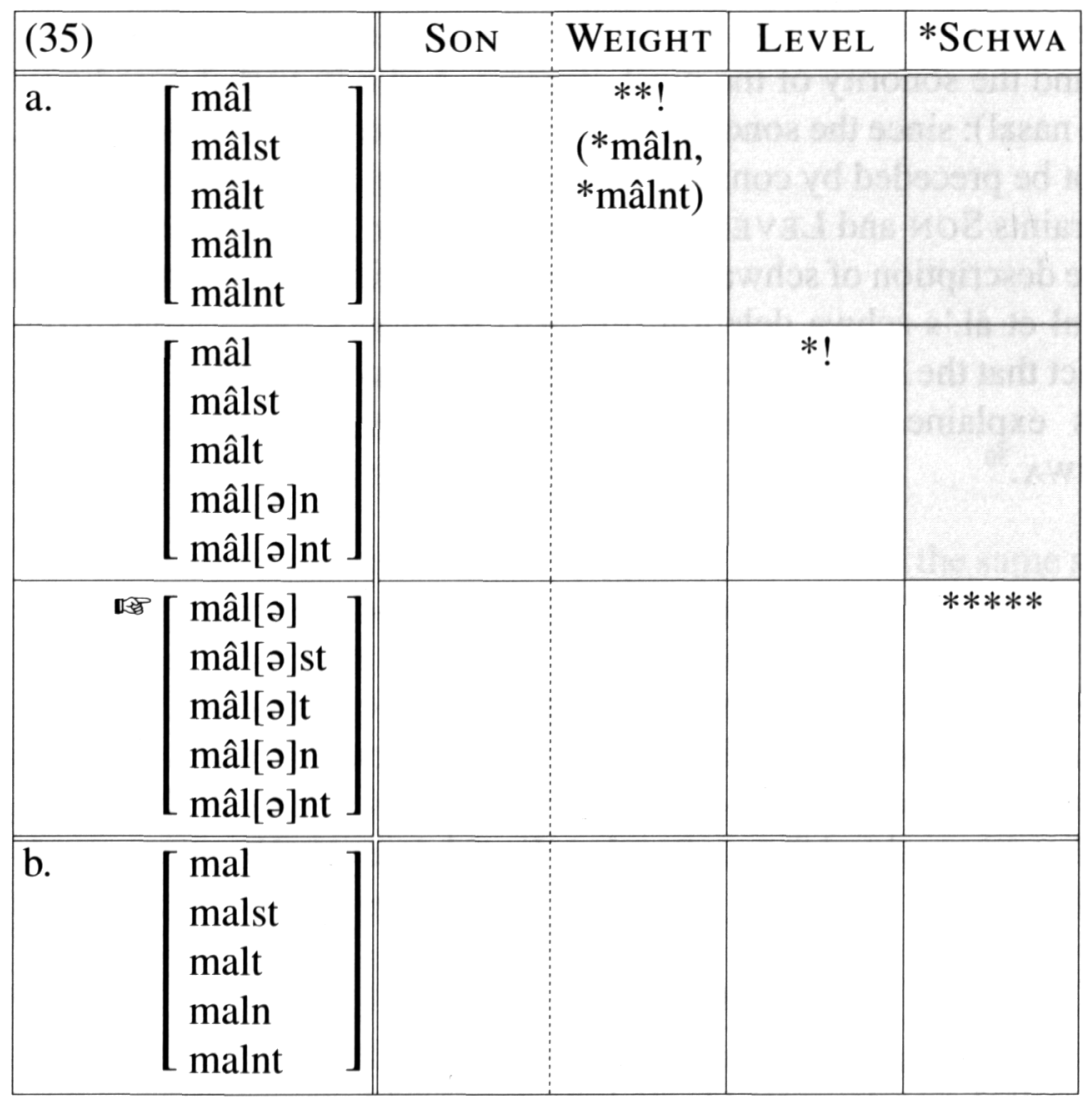

Tableau (35) shows that the paradigms of verbs with a short stem vowel followed by a short liquid like maln 'to grind' differ from other MHG verbs in that none of their members need schwas to avoid Son or WEIGHT violations. ${ }^{28}$ Consequently, such paradigms satisfy LEVEL even if all schwas delete (including the word-final schwa as shown in (17)). 
The analysis of the distribution of schwa illustrated in tableau (35) does not preclude an analysis of the word-final schwa in the first person singular as an inflectional marker in $\mathrm{MHG} .{ }^{29}$ Clearly, the subsequent restoration of final schwas in the first person singular forms illustrated in (17a) indicates that at some point such schwas were analysed as inflectional suffixes and then spread to all relevant forms by analogical extension.

To summarize, the description in (35) establishes a direct connection between the restriction to liquids in Paul et al.'s schwa-deletion rule (19) and the sonority of the most sonorous suffix in verbal paradigms (i.e. a nasal): since the sonority in codas must decrease, the nasal suffix cannot be preceded by consonants other than liquids. Reference to the constraints SON and LEVEL hence obviates the need to refer to liquids for the description of schwa loss seen in (17a). Similarly the restriction of Paul et al.'s schwa deletion rule (19) to short stems follows from the fact that the heaviest suffix contributes one mora to syllable weight and is explained by ordering WEIGHT and LEVEL higher than *SCHWA. ${ }^{30}$

\subsection{Schwa loss in feminine count nouns}

Consider next the loss of final schwa in feminine count nouns described in rule (19). In NHG the final schwa in such nouns is often analysed as a morpheme encoding feminine gender. As is shown by the data in (36) that schwa also deleted after short liquids preceded by short vowels in $\mathrm{MHG}^{31}$

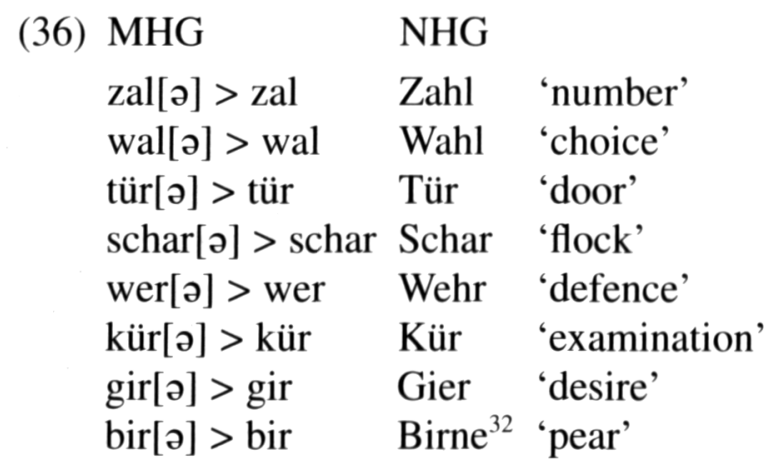


After long stem vowels, long liquids or non-liquid consonants schwas have been stable as is illustrated by the feminine nouns in $(37 a, b) .{ }^{33}$

$\begin{array}{lll}\text { MHG } & \text { NHG } & \\ \text { a. huor[ə] } & \text { Hur[ə] } & \text { 'whore' } \\ \text { hell[ə] } & \text { Höll[ə] } & \text { 'hell' } \\ \text { vîl[ə] } & \text { Feil[ə] } & \text { 'file' } \\ \text { kapéll[ə] } & \text { Kapéll[ə] } & \text { 'chapel' } \\ \text { biul[ə] } & \text { Beul[ə] } & \text { 'bump' } \\ \text { sêl[ə] } & \text { Seel[ə] } & \text { 'soul' } \\ \text { grill[ə] } & \text { Grill[ə] } & \text { 'cricket' } \\ \text { b. bët[ə] } & \text { Bitt[ə] } & \text { 'plea' } \\ \text { woch[ə] } & \text { Woch[ə] } & \text { 'week' } \\ \text { hev[ə] } & \text { Hef[ə] } & \text { 'yeast' } \\ \operatorname{tasch[ə]~} & \text { Tasch[ə] } & \text { 'bag' } \\ \operatorname{deck[ə]} & \text { Deck[ə] } & \text { 'blanket' } \\ \text { van[ə] } & \text { Fahn[ə] } & \text { 'flag' } \\ \text { sit[ə] } & \text { Sitt[ə] } & \text { 'custom' }\end{array}$

The observation that the nouns in (36) and (37) exhibit the same schwa deletion pattern as the inflected verbs in (17) and (18) leads one to suspect that the most sonorous suffix occurring in the nominal paradigms is also a nasal. In fact, all nouns in (36) and (37) are members of paradigms which include no suffix other than $n$. The so-called "strong declension" is represented by the paradigm of bëte 'plea' in (38a) and the "weak declension" is represented by the paradigm of the noun huore 'whore' in (38b): ${ }^{34}$

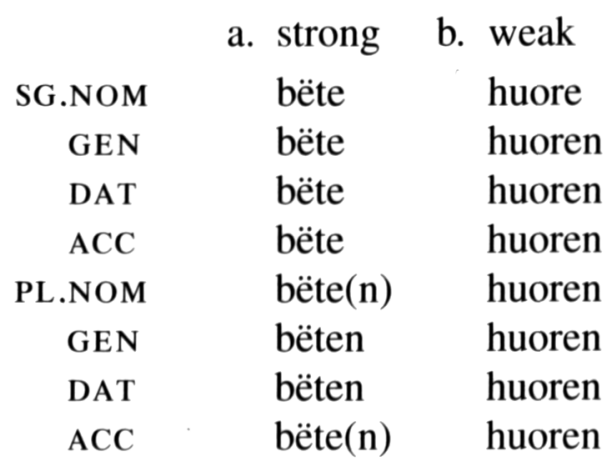


In paradigms which belong to the strong declension, the suffixed plural nominative and accusative forms replaced the earlier forms ending in schwa already in MHG. To illustrate the evaluation of the nouns in (36) and (37) it suffices to represent the paradigms by listing only the phonologically distinct members as is shown in tableau (39):

\begin{tabular}{|c|c|c|c|c|c|}
\hline \multicolumn{2}{|c|}{ (39) } & \multirow{2}{*}{$\frac{\text { SoN }}{* * !}$} & \multirow[t]{2}{*}{ WEIGHT } & \multirow[t]{2}{*}{ LEVEL } & \multirow[t]{2}{*}{ *SCHWA } \\
\hline a. & {$\left[\begin{array}{l}\text { bët } \\
\text { bëtn }\end{array}\right]$} & & & & \\
\hline & {$\left[\begin{array}{l}\text { bët } \\
\text { bët[ə]n }\end{array}\right]$} & & & $* !$ & \\
\hline & {$\left[\begin{array}{l}\text { bët[ə] } \\
\text { bët[ə]n }\end{array}\right]$} & & & & $* *$ \\
\hline b. & {$\left[\begin{array}{l}\text { huor } \\
\text { huorn }\end{array}\right]$} & & $* !$ & 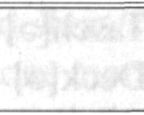 & 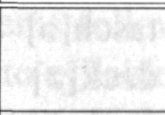 \\
\hline & {$\left[\begin{array}{l}\text { huor } \\
\text { huor[ə]n }\end{array}\right]$} & & & $* !$ & folvis \\
\hline & {$\left[\begin{array}{l}\text { huor }[\text { ə] } \\
\text { huor}[ə] \mathrm{n}\end{array}\right]$} & & & & $* *$ \\
\hline c. & {$\left[\begin{array}{l}\text { zal } \\
\text { zaln }\end{array}\right]$} & & & & \\
\hline
\end{tabular}

Again, the only nouns which require no schwa to satisfy Son, WEIGHT, and LEVEL are those with a short stem vowel followed by a short liquid as is shown in tableau (39c).

The defectiveness of certain noun paradigms yields an additional argument for the analysis illustrated in tableau (39). If the final schwa in for example bët[ə] were indeed stabilized by the schwa in bët $[\partial] n$, which is needed to avoid a Son violation, then final schwas should disappear in phonologically similar nouns whose paradigms lack suffixed forms. For an illustration of this point consider the evaluation of the MHG count noun ruote 'rod' (NHG Rute) and the MHG abstract noun huote 'care' (NHG Hut), which differ in that only ruote can be pluralized. ${ }^{35}$ This difference determines the stability of the final schwa as is shown in tableau (40): 


\begin{tabular}{|c|c|c|c|c|c|}
\hline \multicolumn{2}{|l|}{ (40) } & Son & WEIGHT & LEVEL & *SCHWA \\
\hline a. & {$\left[\begin{array}{l}\text { ruot } \\
\text { ruotn }\end{array}\right]$} & $* !$ & & & \\
\hline & {$\left[\begin{array}{l}\text { ruot } \\
\operatorname{ruot}[\partial] n\end{array}\right]$} & & & $* !$ & \\
\hline $\log \left[\begin{array}{l}1 \\
1\end{array}\right.$ & {$\left[\begin{array}{l}\operatorname{ruot}[\partial] \\
\operatorname{ruot}[\partial] n\end{array}\right]$} & & & & $* *$ \\
\hline \multicolumn{6}{|c|}{ b. huot } \\
\hline & huot[ə] & & & & $* !$ \\
\hline
\end{tabular}

This point is further illustrated by evaluating the minimal pair MHG huore 'whore' (NHG Hure) and the non-count noun MHG ruore 'dysentery' (NHG Ruhr). In this case the crucial difference is that the paradigm of huore, but not that of ruore, includes a member in which the schwa is needed to satisfy WEIGHT:

\begin{tabular}{|c|c|c|c|c|c|}
\hline \multicolumn{2}{|c|}{ (41) } & \multirow[t]{2}{*}{ Son } & \multirow{2}{*}{$\begin{array}{c}\text { WEIGHT } \\
* !\end{array}$} & \multirow[t]{2}{*}{ LEVEL } & \multirow[t]{2}{*}{ *SCHWA } \\
\hline a. & {$\left[\begin{array}{l}\text { huor } \\
\text { huorn }\end{array}\right]$} & & & & \\
\hline & {$\left[\begin{array}{l}\text { huor } \\
\text { huor[ə]n }\end{array}\right]$} & & & $* !$ & \\
\hline & {$\left[\begin{array}{l}\text { huor }[\partial] \\
\text { huor[ə]n }\end{array}\right]$} & & & & $* *$ \\
\hline \multicolumn{6}{|c|}{ b. ruor } \\
\hline & ruor[ə] & & & & $* !$ \\
\hline
\end{tabular}

A comparison of the feminine-noun paradigms in (38) shows that the paradigms of non-count nouns do not necessarily lack suffixed members. Only the paradigms of strong non-pluralizable nouns have no suffixed members. These two conditions hold for both MHG huot[ə] 'care' and ruor[a] 'dysentery', as well as the other feminine nouns listed in (42). The constraint ranking in tableau (41) accounts for the fact that the final schwa disappeared regardless of the sonority or length of the preceding segments: ${ }^{36}$ 
(42)

$\begin{array}{lll}\text { MHG } & \text { NHG } & \\ \text { scham[ə] > scham } & \text { Scham } & \text { 'shame' } \\ \text { vorht[ə] > vorht } & \text { Furcht } & \text { 'fear' } \\ \text { zier[ə] > zier } & \text { Zier } & \text { 'ornament' } \\ \text { pîn[ə] > pîn } & \text { Pein } & \text { 'pain' } \\ \text { smâh[ə] > smâh } & \text { Schmach 'disgrace' } \\ \text { kost[ə] > kost } & \text { Kost } & \text { 'food' } \\ \text { aht[ə] > aht } & \text { Acht } & \text { 'attention' } \\ \text { âht[ə] }>\text { âht } & \text { Acht } & \text { 'outlawry' } \\ \text { natûr[ə] > natûr } & \text { Natur } & \text { 'nature' } \\ \text { mær[ə] > mær } & \text { Mär } & \text { 'fame' } \\ \text { schiuh[ə] > schiuh } & \text { Scheu } & \text { 'repugnance' } \\ \text { schouw[ə] > schouw } & \text { Schau } & \text { 'spectacle' } \\ \text { witz[ə] > witz } & \text { Witz }{ }^{37} & \text { 'wisdom' }\end{array}$

The claim that the schwa loss in the feminine non-count nouns (e.g. $\operatorname{huot}([ə]), \operatorname{ruor}([ə]))$ vis-à-vis the stability of the final schwa in the phonologically similar count nouns (e.g. ruot [ə], huor[ə]) is conditioned not by their semantic difference but rather by the absence of suffixed members in the respective paradigms is supported by the phonological development of the weak non-count nouns. The paradigms of those nouns include no plural forms but suffixed oblique forms as is illustrated with the MHG asche 'ashes' in (43b):

\begin{tabular}{|c|c|}
\hline SG.NOM & huote (>huot) \\
\hline GEN & huote (>huot) \\
\hline DAT & huote (>huot) \\
\hline $\mathrm{ACC}$ & huote (>huot) \\
\hline
\end{tabular}

In tableau (44) it is seen that the stability of the final schwa in asche is correctly predicted by the constraint ranking established above: 


\begin{tabular}{|l||c|c|c|c|}
\hline (44) & SON & WEIGHT & LEVEL & *SCHWA \\
\hline \hline $\left.\begin{array}{l}\text { asch } \\
\text { aschn }\end{array}\right]$ & $* !$ & & & \\
\hline$\left[\begin{array}{l}\text { asch } \\
\text { asch[ə]n }\end{array}\right]$ & & & $* !$ & \\
\hline $\left.\begin{array}{l}\text { asch[ə] } \\
\text { asch[ə]n }\end{array}\right]$ & & & & $* *$ \\
\hline
\end{tabular}

Membership in the weak declension also accounts for the stability of the final schwa in the MHG nouns sunne 'sun' (NHG Sonne) and galle 'gall' (NHG Galle), which occur only as singular nouns. It is thus not the semantic property of pluralizability per se but rather the form of the other paradigm members which determines the stability of the final schwa. That is, schwa is stable if the paradigm includes a member which violates Son or Weight, and deletes otherwise. Note that reference to the notion of a paradigm is crucial for capturing the generalization that the final schwa disappeared only in the subset of the unpluralizable nouns which have no suffix in the oblique cases.

There is only one phonological restriction on schwa loss in words whose paradigms include only suffixless members: schwas fail to delete after voiced obstruents. This restriction has been referred to as Voice Stability Effect in the preceding section and accounts for the stability of the final schwa in the feminine non-count nouns in (45): ${ }^{38}$

\section{(45) MHG NHG}

$\begin{array}{lll}\text { schand[ə] } & \text { Schand[ə] } & \text { 'disgrace' } \\ \text { ebb[ə] } & \text { Ebb[ə] } & \text { 'low tide' } \\ \text { sîd[ə] } & \text { Seid[ə] } & \text { 'silk' } \\ \text { erd[ə] } & \text { Erd[ə] } & \text { 'earth' } \\ \operatorname{krîd}[ə] & \text { Kreid[ə] } & \text { 'chalk' } \\ \operatorname{hir}[z][ə] & \text { Hir[z][ə] } & \text { 'millet' } \\ \text { lieb[ə] } & \text { Lieb[ə] } & \text { 'love' } \\ \operatorname{genad[ə]} & \text { Gnad[ə] } & \text { 'mercy' } \\ \text { han[z][ə] } & \operatorname{Han}[\mathrm{z}][ə] & \text { 'Hanseatic League' }\end{array}$

The Voice Stability Effect is obscured in words which belong to para- 
digms which include a nasal suffix because in such words schwas are stable after any obstruent. Similarly the Voice Stability Effect is obscured in historical dactyls like MHG lébende 'alive' because in such words schwas deleted to satisfy the constraint $\left(\sigma^{2}\right)_{\mathrm{F}}$ regardless of the preceding consonant (e.g. lébende > lében $[t]$ ). The constraint ranking in (46) thus accounts for all data considered so far:

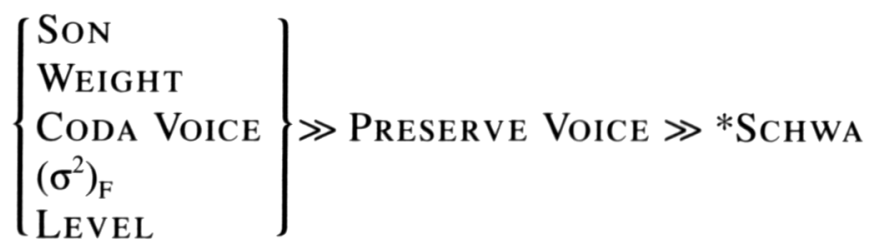

In the following sections additional data will be presented which allow one to establish further rankings between the constraints in (46).

\subsection{Schwa loss in masculine nouns}

Consider the loss of final schwa in masculine count nouns. Those nouns are generally weak, which means that all other forms in their paradigms end in $n$ (cf. (38b)). Schwa loss in nouns with a short stem vowel followed by a short liquid like MHG star([ə]) 'starling' is therefore expected (see 47a). In all other nouns final schwas should be stable. ${ }^{39}$ The nouns in (47b) illustrate the stabilizing effect of either vocalic or consonantal length. The data in (47c) show that schwa is stable after nasals and obstruents ( $\dagger$ indicates that the word is archaic).

\begin{tabular}{|c|c|c|}
\hline MHG & NHG & \\
\hline $\operatorname{star}[\partial]>\operatorname{star}$ & Star & 'starling' \\
\hline $\operatorname{ber}[ə]>$ ber & Bär & 'bear' \\
\hline $\operatorname{ar}[\partial]>\operatorname{ar}$ & Aar & 'eagle' \\
\hline stör[ə] > stör & Stör & 'sturgeon' \\
\hline ster[ə] > ster & †Stär & 'ram' \\
\hline farr[ə] & †Farre & 'bull' \\
\hline bull $[ə]^{40}$ & Bulle & 'bull' \\
\hline geséll[ə] & Gesélle & 'house mate' \\
\hline buol[ə] & Buhle & 'lover' \\
\hline
\end{tabular}


c. valk[ə]

aff[ə]

an[ə]

ohs[ə]
Falke 'falcon'

Affe 'monkey'

Ahne 'grandfather'

Ochse 'ox'

The familiar constraint ranking in tableau (48) illustrates the analysis of final schwa loss seen in the data in (47):

\begin{tabular}{|c|c|c|c|c|c|}
\hline \multicolumn{2}{|l|}{$(48)$} & Son & WEIGHT & LEVEL & *SCHWA \\
\hline a. $\left[\begin{array}{l}\mathrm{s} \\
\mathrm{s}\end{array}\right.$ & $\left.\begin{array}{l}\text { star } \\
\text { starn }\end{array}\right]$ & & & $\sqrt{20 x y}$ & 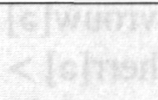 \\
\hline & $\begin{array}{l}\text { star } \\
\operatorname{star}[\partial] n]\end{array}$ & & & $* !$ & \\
\hline & $\begin{array}{l}\text { star[ə] } \\
\operatorname{star}[\partial] n]\end{array}$ & & & & $* * !$ \\
\hline b. & $\left.\begin{array}{l}\text { farr } \\
\text { farrn }\end{array}\right]$ & & $* !$ & & icher \\
\hline & $\left.\begin{array}{l}\text { farr } \\
\text { farr[ə]n }\end{array}\right]$ & & & $* !$ & 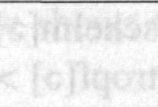 \\
\hline & $\begin{array}{l}\text { farr[ə] } \\
f \operatorname{arr}[\partial] \mathrm{n}\end{array}$ & & & & $* *$ \\
\hline c. & $\left.\begin{array}{l}\text { valk } \\
\text { valkn }\end{array}\right]$ & $* !$ & & & \\
\hline & $\begin{array}{l}\text { valk } \\
\text { valk[ə]n] }\end{array}$ & & & $* !$ & \\
\hline$\left[\begin{array}{l}\mathrm{v} \\
\mathrm{v}\end{array}\right.$ & 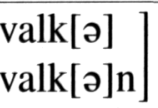 & & & & $* *$ \\
\hline
\end{tabular}

The claim that the final schwa in the data in $(47 \mathrm{~b}, \mathrm{c})$ is stabilized by leveling is supported by the systematic schwa loss in non-count nouns whose paradigms include no members which violate Son or WEIGHT (e.g. MHG mët([ə]) 'mead' (NHG Met), MHG küt([ə]) 'resin' (NHG Kitt)). In masculine nouns whose paradigms include no suffixed forms the final schwa is stable only if preceded by a voiced obstruent (e.g. MHG $k a[z][ə]$ (NHG Käse) 'cheese'). ${ }^{41}$ 
Recall that the paradigms of weak nouns always include members with a nasal suffix. Therefore the word-final schwa in weak nouns is predicted to be stable due to LEVEL effects unless the stem consists of a short vowel followed by a short liquid. There are, however, two types of weak nouns where the final schwa disappeared regardless of the length or the sonority of the preceding segments: nouns which are used as titles (cf. (49a)) and nouns which are used as swear words in MHG (cf. (49b)): ${ }^{42}$

MHG NHG

a. vrouw $[$ ə] $>$ vrouw Frau 'female ruler' herr[ə] $>$ herr Herr 'lord'

vürst[ə] $>$ vürst Fürst 'ruler'

grâv[ə] > grâv Graf 'count'

prinz[ə] $>$ prinz Prinz 'prince'

schenk[ə] > schenk Schenk 'cupbearer'

b. $\operatorname{geck}[$ ə] $>$ geck Geck 'silly person'

lump[ə] $>$ lump Lump 'person dressed in rags'

narr[ə] > narr Narr 'fool'

schelm[ə] > schelm Schelm 'dead person; carcass'

tropf[ə] $>$ tropf Tropf 'pathetic or stupid person'

tôr[ə] $>$ tôr Tor 'confused person'

The nouns in (49a) and (49b) are frequently used in the function of direct address and hence occur as vocatives. This observation is relevant to the exceptional schwa loss in (49) if we make two assumptions. First, unlike the case forms in (38), vocatives do not belong to inflectional paradigms (cf. Glück $1993^{43}$ ). Consequently there are no Level effects and word-final schwa disappears. ${ }^{44}$ This analysis raises the question of why schwa also disappeared in the nominative form, which clearly does belong to an inflectional paradigm containing suffixed forms and hence should exhibit LEVEL effects. The second assumption is accordingly that the nominative form must be identical to the vocative and that this requirement dominates LEVEL. Identity requirements pertaining to word forms which share few or no morphological features (and may well belong to separate paradigms) are attested universally and are in fact cited as the main argument in support of the word and paradigm model (cf. Matthews 1991: 185ff). ${ }^{45}$ 


\subsection{The ranking of LEVEL with respect to other constraints}

Recall that schwa loss in adjectives like MHG éllènd [a] (NHG élèn $[t]$ ) indicates that the constraint $\left(\sigma^{2}\right)_{\mathrm{F}}$ dominates the constraint PRESERVE Voice. Schwa loss in MHG nouns like gégend[ə] 'area' (NHG Gégen $[t])$ indicates that $\left(\sigma^{2}\right)_{\mathrm{F}}$ dominates the constraint LEVEL as well.

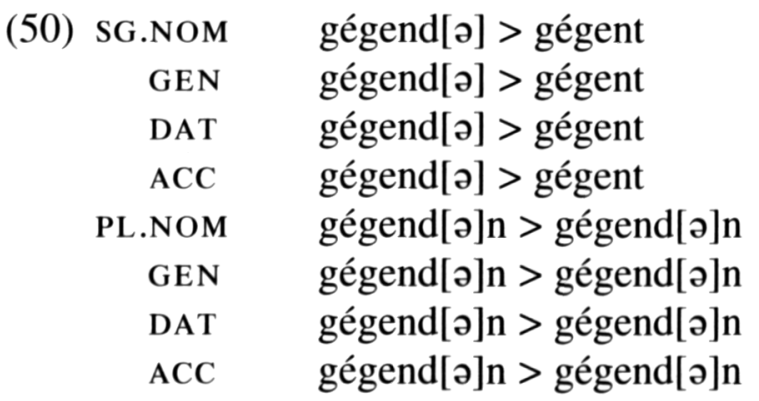

The data in (50) show not only that $\left(\sigma^{2}\right)_{\mathrm{F}}$ dominates both Preserve Voice and Level but also that $\left(\sigma^{2}\right)_{\mathrm{F}}$ is violable. Specifically, the stability of both schwas in words like gég[ə]nd[ə]n shows that SoN ranks higher than $\left(\sigma^{2}\right)_{\mathrm{F}}$ as is shown in tableau (51).

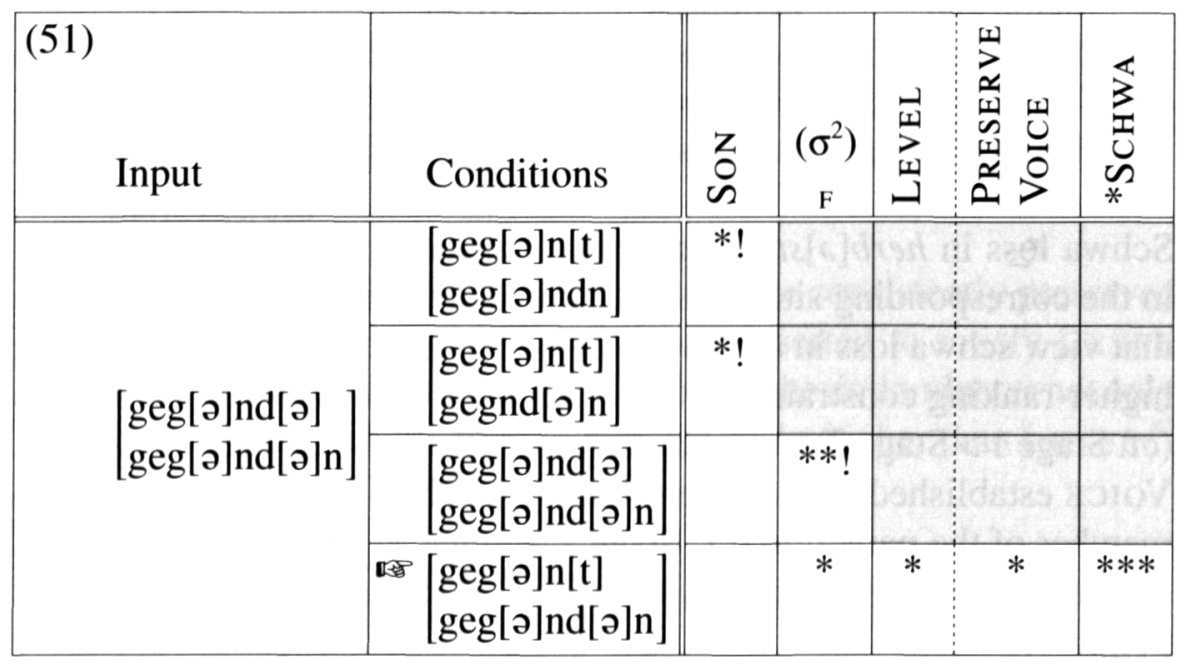

The interaction between the constraints in tableau (51) can be further determined on the basis of the historical schwa loss in the data in (52): ${ }^{46}$ 
(52) $\mathrm{MHG}$

NHG

herb[ə]st $>$ her[p]st Herbst autumn

krëb[ə]3 > krë[p]3 Krebs 'crab'

houb[ə]t $>$ hou[p]t Haupt 'head'

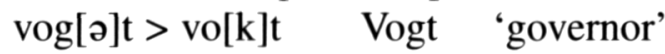

$\operatorname{mag}[$ [ə]t $>$ ma[k]t Magd 'maid'

bâb[ə]s > bâ[p]s Papst 'pope'

abb[ə]t $>$ a[p]t Abt 'abbot'

jag[ə]t $>$ ja[k]t Jagd 'hunting'

$\mathrm{amb}[$ ə]t $>$ am[p]t Amt 'office'

$o b[ə] 3>o[p] 3 \quad$ Obst 'fruit'

The schwa loss seen in (52) appears to contradict the claim that PRESERVE VoICE dominates *SCHWA, as was established in Section 2. However, the contradiction disappears when the developments of the complete paradigms are considered. Consider the three stages in the development of the paradigm of the MHG noun herbest 'harvest, autumn' in (53):

(53) Stage 1

Stage 2 Stage 3

her.b[ə]st her.b[ə]st her[p]st

her.b[ə].st[ə]s her[p].st[ə]s her[p].st[ə]s

her.b[ə].st[ə] her[p].st[ə] her[p].st[ə]

her.b[ə].st[ə]n her[p].st[ə]n her[p].st[ə]n

Schwa loss in herb[a]st is arguably a consequence of the schwa loss in the corresponding site in the dactylic members of the paradigm. On that view schwa loss in herb[a]st served not to satisfy *SCHWA but the higher-ranking constraint LEVEL. The initial schwa loss in the dactyls (cf. Stage $1>$ Stage 2 ) supports the ranking $\left(\sigma^{2}\right)_{\mathrm{F}} \gg$ LEVEL, PRESER VE VoICE established above. The subsequent schwa loss in the unsuffixed member of the paradigm (cf. Stage $2>$ Stage 3) indicates that LEVEL dominates the constraint Preser ve VoICE. Tableau (54) illustrates this point: 


\begin{tabular}{|c|c|c|c|c|}
\hline (54) Input & Candidates & $\left(\sigma^{2}\right)_{\mathrm{F}}$ & LEVEL & $\begin{array}{l}\text { Preserve } \\
\text { VoICE }\end{array}$ \\
\hline \multirow{3}{*}{$\begin{array}{l}\text { her.b[ə]st } \\
\text { her.b[ə].st[ə]s } \\
\text { her.b[ə].st[ə] } \\
\text { her.b[ə].st[ə]n }\end{array}$} & $\begin{array}{l}\text { her.b[ə]st } \\
\text { her.b[ə].st[ə]s } \\
\text { her.b[ə].st[ə] } \\
\text { her.b[ə].st[ə]n }\end{array}$ & $* * *$ ! & & \\
\hline & {$\left[\begin{array}{l}\text { her.b[ə]st } \\
\text { her[p].st[ə]s } \\
\text { her[p].st[ə] } \\
\text { her[p].st[ə]n }\end{array}\right.$} & & $* * * !$ & \\
\hline & {$\left[\begin{array}{l}\text { her[p]st } \\
\text { her[p].st[ə]s } \\
\text { her[p].st[ə] } \\
\text { her[p].st[ə]n }\end{array}\right.$} & & $* *$ & $* * * *$ \\
\hline
\end{tabular}

The third paradigm in tableau (54) is more leveled than the second one because there are only two consonants which appear in the syllable head position in some members but in coda position in others (i.e. $s, t$ ). This raises the question of how to eliminate the candidate in (55), which incurs no LEVEL violations:

$$
\text { (55) } \begin{aligned}
& \text { her[p].st[ə] } \\
& \text { her[p].st[ə]s } \\
& \text { her[p].st[ə] } \\
& \text { her[p].st[ə]n }
\end{aligned}
$$

The observation that existing final schwas were consistently preserved to satisfy LEVEL in MHG but were never inserted to satisfy LEVEL indicates that the constraint against vowel epenthesis dominates not only Preserve Voice (cf. Section 2), but also ranks higher than Level. ${ }^{47}$

\subsection{Schwa loss in neuter nouns}

Unlike the count nouns considered so far neuter count nouns lose their final schwa even after consonants other than liquids (cf. (56a)) and after long segments (cf. (56b)): 
(56) MHG NHG

a. stück[ə] > stück Stück 'piece' netz[ə] $>$ netz Netz 'net' hirn[ə] $>$ hirn Hirn 'brain' kinn[ə] $>$ kinn Kinn 'chin' kriuz[ə] $>$ kriuz Kreuz 'cross' rîch[ə] > rîch Reich 'empire' heft[ə] $>$ heft Heft 'handle' vletz[o] > vletz Flöz 'hallway'

b. œr[ə] $>$ œ̌r Öhr 'eye' mûl[ə] > mûl Maul 'mouth'

The fact that the patterns of schwa deletion in neuter count nouns differ from those in other count nouns is perhaps conditioned by the structure of the strong neuter paradigm, to which almost all neuter nouns which ended in schwa in MHG belong. ${ }^{48}$ The strong neuter paradigm, illustrated in (57a), differed from the paradigms considered so far in that it lacked a plural marker. Compare the paradigm of the neuter noun stücke 'piece' with the paradigms of the non-neuter nouns brücke 'bridge' and mücke 'midge'. The paradigm of the weak noun mücke is representative of almost all non-neuter nouns which end in schwa.

\begin{tabular}{|c|c|c|c|}
\hline & $\begin{array}{l}\text { strong } \\
\text { (neuter) }\end{array}$ & $\begin{array}{l}\text { strong } \\
\text { (feminine) }\end{array}$ & $\begin{array}{l}\text { c. weak } \\
\text { (feminine, } \\
\text { masculine) }\end{array}$ \\
\hline SG.NOM & stücke (>stück) & brücke & mücke \\
\hline GEN & stückes (>stücks) & brücke & mücken \\
\hline DAT & stücke (>stück) & brücke & mücken \\
\hline $\mathrm{ACC}$ & stücke (>stück) & brücke & mücken \\
\hline PL.NOM & stücke & brücken & mücken \\
\hline GEN & stücke & brücken & mücken \\
\hline DAT & stücken & brücken & mücken \\
\hline $\mathrm{ACC}$ & stücke & brücken & mücken \\
\hline
\end{tabular}

The fact that schwa disappeared only in neuter singular nouns can be explained by introducing the morphological constraint $P_{L} \neq$ SG defined in (58) which dominates LEVEL: 
$P_{L} \neq S G$

At least one plural form must be morphologically marked with respect to the corresponding singular form such that the marker occurs in all plural forms in the paradigm.

The specification "at least one plural form" in (58) is motivated by the observation that in weak paradigms only the nominative plural is marked with respect to the corresponding singular form. The requirement that the relevant marker must occur in all plural forms of the paradigm is meant to ensure that for instance the suffix $-n$ in $(57 b, c)$, but not in (57a), is analysable as a plural marker.

As a result of schwa loss in the singular forms in (57a) schwa emerges as a plural marker in the plural forms thereby satisfying $\mathrm{PL}_{\mathrm{L}} \neq \mathrm{SG}$. By contrast, the constraint $\mathrm{PL}_{\mathrm{L}} \neq \mathrm{SG}$ is satisfied by the suffix $-n$ in the paradigms of brücke and mücke with the result that schwa loss is inhibited by the lower-ranking constraint LEVEL. The deletion patterns in the paradigms represented in (57) can thus be described without reference to gender.

The disappearance of word-final schwas in all dactylic word forms including all plural forms indicates that the constraint $\left(\sigma^{2}\right)_{\mathrm{F}}$ dominates $\mathrm{PL}_{\mathrm{L}} \neq \mathrm{SG}$. As examples, consider the schwa loss in the paradigms of the masculine noun MHG jegere 'hunter' and the neuter noun mezzere 'knife' in (59):

$$
\begin{gathered}
\text { SG.NOM jéger[ə] }>\text { jéger } \\
\text { GEN jéger[ə]s }>\text { jégers } \\
\text { DAT jéger[ə] > jéger } \\
\text { ACC jéger[ə] > jéger } \\
\text { PL.NOM jéger[ə] > jéger } \\
\text { GEN jéger[ə] > jéger } \\
\text { DAT jéger[ə]n }>\text { jégern } \\
\text { ACC jéger[ə] }>\text { jéger }
\end{gathered}
$$

$$
\begin{aligned}
& \text { mézzer[ə] > mézzer } \\
& \text { mézzer[ə]s > mézzers } \\
& \text { mézzer[ə] > mézzer } \\
& \text { mézzer[ə] > mézzer } \\
& \text { mézzer[ə] > mézzer } \\
& \text { mézzer[ə] > mézzer } \\
& \text { mézzer[ə]n > mézzern } \\
& \text { mézzer[ə] > mézzer }
\end{aligned}
$$

The claim that $\mathrm{PL}_{\mathrm{L}} \neq \mathrm{SG}$ dominates LEVEL implies that it dominates the constraint Preserve Voice as well (cf. the ranking in tableau (54)). As a result it is predicted that schwas preceded by voiced obstruents are stable in neuter nouns which lack plural forms but delete in strong 
neuter count nouns. Unfortunately there are almost no data relevant to this prediction. ${ }^{49}$ The schwa loss in the neuter count nouns hemde $>$ hemt (NHG Hemd) 'shirt' and bilde > bilt (NHG Bild) 'picture' is consistent with the ranking $\mathrm{PL}_{\mathrm{L}} \neq \mathrm{SG} \gg$ PRESERVE VOICE but does not necessarily support it. ${ }^{50}$

\section{Conclusion}

Schwa loss in German has generally been described in terms of contextsensitive deletion rules of the type shown in (60) (cf. Paul et al. 1989, Wurzel 1970):

(60) $ə \rightarrow \varnothing / X-Y$

While it may seem intuitively plausible to describe schwa loss in terms of deletion as in (60) it can be shown that a more general description is possible in terms of conditions for stability. Such a description presupposes the constraint $*$ SCHWA. Contextual restrictions on schwa deletion are described by constraints which dominate *ScHWA as is shown in (61). The claim is then that schwa disappears unless it is needed to satisfy higher-ranking constraints.

(61) Constraint $1, \ldots$, Constraint Co $_{1} \gg$ Schwa $^{2}$

The constraints dominating *SCHWA identified here are shown in (62):

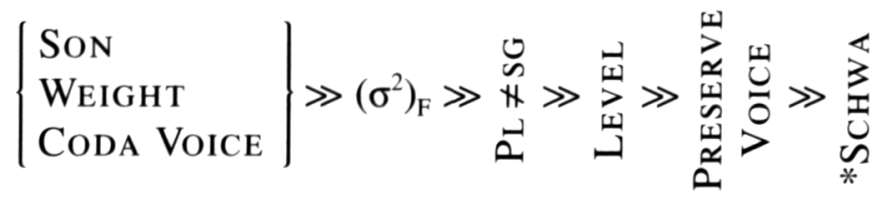

The basic generalisation expressed in (62) is that final schwa in MHG deletes unless one of the three high-ranking constraints on syllabic wellformedness is violated. In inflected words this generalisation can be obscured by LEVEL effects. That is, for words which belong to a paradigm schwas are stable if the paradigm includes a member which requires schwa for phonological reasons. Both the LEVEL Stability 
Effect and the Voice Stability Effect fail in dactyls because of a higher ranking constraint which limits the size of feet. The type of conditions which determine the stability of word-final schwas can accordingly be classified as in (63). ${ }^{51}$

\begin{tabular}{|c|c|c|c|c|}
\hline $\begin{array}{l}\text { 3) Constraints on } \\
\text { the wellformed- } \\
\text { ness of syllable } \\
\text { structure }\end{array}$ & $\gg$ & $\begin{array}{l}\text { Constraints on } \\
\text { the well- } \\
\text { formedness of } \\
\text { foot structure }\end{array}$ & $\gg$ & $\begin{array}{l}\text { Constraints on } \\
\text { the wellformed- } \\
\text { ness of para- } \\
\text { digm structure }\end{array}$ \\
\hline
\end{tabular}

While the context for deletion requires reference to disjoint classes (e.g., the class of sonorants and voiceless obstruents in (5)), highly specific and seemingly arbitrary segment classes (e.g. the class of short liquids in (19)), as well as a number of highly idiosyncratic semantic and morphosyntactic features (e.g. restriction to count nouns, strong neuter nouns, inflected adjectives) reference to all of these properties can be dispensed with when the conditions for schwa stability are described instead. The description of stability conditions can be based entirely on independently motivated constraints as shown in (62) provided that the notion of the paradigm and the constraint $*$ SCHWA are recognized. The notion of the paradigm has generally been ignored in Structuralist or Generative work but played a prominent role in Neogrammarian descriptions of language change. The analysis in (62) challenges the Neogrammarian view in that paradigmatic leveling does not (necessarily) presuppose a process by which forms having undergone regular phonetic change are restored due to analogical pressure. Rather analogical pressure serves as a constraint on the progess of regular sound change (e.g. schwa loss). That is, on the description in (62) certain schwas are analogically retained rather than restored. ${ }^{52}$

Consider finally the constraint *SCHWA, which raises the question of why schwas are undesirable (or marked). The relevant property is presumably not lack of stress because the unstressed high vowel [I], which is an allophonic variant of schwa occurring before high consonants in MHG, is generally stable (cf. the dactyls Kön[I]ge 'kings', Krán[I]che 'cranes'). This suggests that schwas are marked because they lack place features, and that perhaps $*$ SCHWA should be replaced by a constraint * [-PLACE], which prohibits placeless segments. How- 
ever, a fresh look at the contexts in which vowel (or segment) loss occurs in cross-linguistic perspective may reveal that the relevant data are in general better described in terms of stability conditions than in terms of deletion rules. If this were the case this would argue for the replacement of *SCHWA by a more general constraint *VOWEL, which prohibits vowels, or even *SEGMENT, which prohibits segments, which in MHG happens to be dominated by a constraint Preserve Place, which requires the preservation of segments containing place features.

\section{Acknowledgements}

This paper was first presented at the workshop "Markedness and Language Change" in Schloß Maurach in March 1997. I thank the participants there for a lively discussion. In particular I thank Aditi Lahiri for helpful comments on the written version and Bruce Straub for proofreading.

\section{Notes}

1. The data are based on Lexer (1878) and Drosdowski (1989).

2. This number excludes neuter nouns which did not have a schwa in MHG such as Getier 'animals' (collective). In addition some MHG neuter nouns with final schwa are excluded because they are synchronically indistinguishable from a class of highly productive nomina actionis. The class in question includes nouns of the type $G e \mathrm{X} e$, where $\mathrm{X}$ is a verb with initial stress, such as Gequatsche 'chattering', Gekichere 'giggling', Getelefoniere 'telephoning', based on the verbs quatschen 'to chat', kichern 'to giggle', telefonieren 'to telephone' (for discussion see Olsen 1991 and references therein). The high productivity of nouns of the type GeXe in German makes it difficult to assess the status of final schwa in a specific small set of MHG collective neuter nouns. Does the existence of NHG Gehetze 'rushing' indicate that the schwa exceptionally failed to delete in the MHG noun gehetze? Or, more likely, did MHG gehetze become obsolete (as did most MHG collective neuter nouns) and NHG Gehetze is an instance of the productive rule mentioned above? In general the two types (i.e. inherited collective nouns versus recently coined nomina actionis) can be clearly distinguished on the basis of semantic, syntactic, and phonological criteria as is illustrated in (ia) versus (ib):

\section{(i) a. Gepäck 'baggage' b. Gepacke 'packing'}

Both the inherited collective noun in (ia) and the productively coined action nominal in (ib) are (etymologically) related to the verb packen 'to pack'. Nouns belonging to the first type are historically based on verbs or nouns, where many of those bases have become obsolete. The stems of the inherited nouns always 
consist of a single foot and often show umlaut. The relation to their etymological base is typically marked by semantic idiosyncrasies. By contrast, nouns which result from the current productive rule are always based on actual verbs, never have umlaut, and the semantic relation to their base is strictly compositional (cf. (ib)). The few MHG nouns which do not allow for a clear classification according to these criteria (i.e. gehetze, gerinne, etc.) have been omitted from consideration in (2).

3. In NHG the type of collective neuter nouns illustrated in (1) differ from adjectives in that dialectal variants without the final schwa are more acceptable for adjectives.

4. The schwa does not delete in adverbs (e.g. dick[ə] satt sein 'to be very full', lang[ə] her sein 'to be a long time ago', etc.), where it functions as a suffix.

5. In addition to blöde 'feeble-minded' there is also a variant blöd 'annoying' in NHG, which presumably originates in German dialects in which final schwa disappeared in all uninflected adjectives. The observation that the two adjectives also differ in meaning shows that they are separate lexical items.

6. This number excludes the NHG word nütze (from MHG nütze), which occurs only in the idiomatic phrase $z u$ etwas/nichts nütze sein 'to be good for something/nothing'. The irregular persistence of the final schwa in nütze is typical for the phonological behavior of words occurring in fossilized phrases. The negated cognate of nütze, the adjective unnütz 'useless' (from MHG unnütze), occurs freely and shows the regular loss of final schwa.

7. It appears that schwa persisted longer after $h$ and after (historical) geminates where stability may correlate with sonority (i.e. the more sonorous the geminates, the more stable the following schwa). For the persistence of schwa in nütze, see n. 6.

8. The observation that schwas tend to disappear unless specific conditions obtain is also supported by the development of schwa in Proto-Slavic. According to Leed schwa disappears in "weak position" but is stable in "strong position". He notes that " $/ \mathrm{\partial} /$ is said to be in strong position when it occurs: (1) before /r/ or /l/ when the resulting sequence occurs between consonants; (2) as the second, or evennumbered $/ \partial /$ in a sequence of syllables containing $/ \partial /$, counting from the end of the word. /a/ is said to be in weak position when it occurs elsewhere ..." (Leed 1958: 15). Crucially, the description focuses on the conditions for schwa stability, rather than the conditions for schwa loss (i.e. the "elsewhere case").

9. Schwa loss in MHG er[a]z[ə] cannot be considered an overall phonological improvement since it resulted in a complex coda (i.e. [erts] 'ore') (cf. the view of language change as "local improvement" in Vennemann 1988). This shows that the constraint *SCHWA dominates the constraint NoCoDA, which requires open syllables (cf. Prince and Smolensky 1993).

10. This description raises the question of whether or not the Voice Stability Effect is contingent on the fact that [ \pm voice] is a contrastive feature in German. Consider noncontrastive features like aspiration or glottalization in American English: voiceless stops are aspirated in onset position but glottalized in coda position. 
Could there for example exist a stability effect in American English which is based on the constraint against aspirated stops in coda position? I suspect that such an effect could not exist but that contrastiveness is a crucial prerequisite for stability effects.

11. In words like strenge 'strict', enge 'narrow', and bange 'anxious' word-final schwa deleted presumably after postnasal g-deletion occurred (e.g. stre [ygə] > stre $[\eta \partial]>\operatorname{stre}[\eta])$. This is because, unlike the obstruent $[\mathrm{g}]$, the nasal $[\mathrm{g}]$ is unmarked for the feature [ \pm voice] in coda position and therefore does not stabilize the following schwa. The deletion of final schwa in those words argues against the analysis proposed by Hall (1992) and Wiese (1994) who derive the velar nasal synchronically from an underlying cluster $/ \mathrm{ng} /$.

12. For instance, in the adjective $t a u[p]$ 'deaf' the voiceless obstruent in coda position alternates with the corresponding voiced obstruent in onset position in all inflected forms (e.g. $\operatorname{tau}[b]+e, \operatorname{tau}[b]+e s, \operatorname{tau}[b]+e m$ ). Yet, analogical levelling never occurs. That is, $\operatorname{tau}[p]$ to $\operatorname{tau}[b]$ is not a possible analogical change in German.

13. Interestingly, Jeffers and Lehiste (1979: 11) note that vowel epenthesis in wordfinal position occurs only to avoid complex clusters. That is, vowel epenthesis after a single consonant (e.g. toub $>$ toube) appears not to be a possible sound change.

14. In accordance with the prosodic hierarchy, feet are limited by phonological word boundaries. The words in (i) differ from words like éllènde, vrémede in that they consist of two phonological words. The schwa in (i) is therefore stable according to the ranking in tableau (14), although the stress contour of those words is similar to that of historically fused compounds like éllènde, in which the schwa disappeared:

(i) $\mathrm{MHG}>\mathrm{NHG}$

$$
\begin{aligned}
& (\text { snít })_{w}(\text { kàese })_{w}>(\text { Schnítt })_{w}(\text { käs }[\partial])_{w} \text { sliced cheese }
\end{aligned}
$$

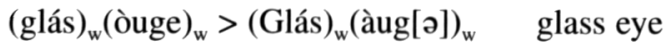

$$
\begin{aligned}
& \text { (vür) })_{w}(\text { sòrge })_{w}>(\text { Für })_{w}(\operatorname{sòrg}[\partial])_{w} \text { welfare } \\
& \text { (úr) })_{\mathrm{w}}(\text { kùnde })_{\mathrm{w}}>(\text { Úr })_{\mathrm{w}}(\text { kùnd[ə] })_{\mathrm{w}} \text { document }
\end{aligned}
$$

15. The constraint in (13) differs from the constraint FTBIN in Prince and Smolensky in that it imposes an upper limit on the size of feet rather than require binary feet. This modification is necessary to account for the general preference of monosyllabic over trochaic forms in German.

16. The restriction to phonological words is motivated by the restrictions illustrated in $\mathrm{n} .14$ and by the observation that there is no Voice Stability Effect in function words (cf. MHG $a[b ə]>a[p]$ 'from', MHG $o[b ə]>o[p]$ 'if'). The claim that function words are not phonological words is based on various phonological properties including the fact that they can disobey minimality conditions (cf. Selkirk 1995, Hall 1999). The absence of the Voice Stability Effect in function words shows that for function words the constraint PRESERvE VoICE does not 
dominate *SchWA. Instead, schwa deletion appears to be determined by sentence intonation. The fact that schwa disappeared in mit [a] > mit (NHG mit) 'with', but not in ân[ə] (NHG ohne) 'without' may well be related to the fact that mit frequently combines with an unstressed determiner (mit der Hoffnung 'with the hope') whereas ohne tends to combine with bare nouns, which typically have initial stress (ohne Hoffnung 'without hope'). That is, the stability of the schwa in ohne serves to yield a pattern of alternating stress.

17. All syllable structure constraints used in my description are based on Vennemann's independently motivated preference laws for syllable structure (cf. Vennemann 1988).

18. Note that the Voice Stability Effect only requires that both Coda Voice and Preserve Voice dominate *Schwa. The irrelevance of the order between Coda Voice and Preserve Voice implies that "Final Devoicing" is not a prerequisite for the Voice Stability Effect.

19. The subsequent analogically conditioned restoration of word-final schwa as an inflectional marker as well as vowel lengthening manifested in the NHG forms is irrelevant to the issue under consideration and will not be discussed.

20. To avoid reference to "stems" one could also refer to "shared" consonants which occur in each member of the paradigm.

21. Those laws say that the more sharply the sonority increases towards the nucleus the more syllable heads and codas are preferred (cf. Vennemann 1988: 13ff).

22. There seems to be general agreement among phonologists that German $r$ is more sonorous than $l$, which in turn is more sonorous than the nasals. The overall structures of the sonority hierarchies proposed, however, differ considerably (cf. Vennemann (1982: 284), Strauss (1982: 97), Hall (1992: 64)).

23. The description in (29) is not entirely satisfactory in that it fails to account for the chronology of schwa loss. For example, schwa in har[a] $m$ disappeared apparently earlier than schwa in hal[a]m, perhaps because of a preference for coda clusters with maximally sharp sonority drops (cf. Vennemann 1988: 21).

24. Constraints which preserve consonants are violable in MHG as is shown by historical developments like MHG we $[r l t]>$ NHG We[lt] 'world', MHG $l a[m p]$ $>$ NHG $L a[m]$ 'lamb'.

25. This restriction has also been claimed to hold for English (cf. Kiparsky 1981).

26. I assume that the input consists of the corresponding paradigm encountered in acquisition.

27. I assume that the final $t$ in malnt is extrasyllabic and hence does not contribute to syllable weight.

28. This account crucially relies on the definition of the paradigm in terms of agreement because past tense forms of the verb maln 'to grind' do require schwa to avoid WEIGHT violations (e.g. muol[ə]n).

29. For example, the final $-n$ in NHG plural forms (e.g. Kindern 'children') clearly functions as a dative marker although its occurrence is phonologically restricted: 
the marker appears only if neither $\left(\sigma^{2}\right)_{\mathrm{F}}$ nor SoN are violated. Otherwise the dative case is unmarked in plural forms.

30. The claim is then that the phonological restrictions on schwa loss in inflected words in MHG can be predicted on the basis of the most sonorous and the heaviest suffix within the inflectional paradigm. To test this claim it would be desirable to investigate paradigms in which the most sonorous suffix is not a nasal or does not weigh one mora. For example, given a paradigm in which $l$ is the most sonorous suffix the constraint ranking in (35) would predict that schwa deletes only after the consonant $r$. Unfortunately, there are very few relevant cases with which to test such predictions. MHG adjectival paradigms are not suited for testing the analysis because of the large number of variants within the so-called strong declension which resulted from the merger of two distinct inflectional systems (i.e. nominal and pronominal) in MHG. However, in NHG adjectival paradigms no longer include variants. The difference in the

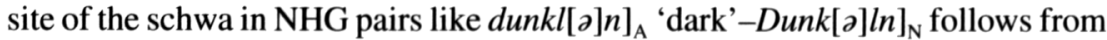
the condition that NHG adjectival paradigms are leveled and the fact that in adjectival paradigms the most sonorous suffix is $r$ while in nominal paradigms it is $n$ (cf. Raffelsiefen 1995).

31. The nouns in (36) are typically represented with both variants in Lexer (e.g. zalzal[ə]; wal-wal[ə]), but with the exception of tür[ə] the form with schwa has become obsolete. The nouns listed below are counter-examples in that the variant with schwa has been retained in NHG while the schwaless variant has become obsolete:

$\begin{array}{lll}\text { (i) } & \text { MHG } & \text { NHG } \\ \text { schal[ə]-schal } & \text { Schale } & \text { 'shell' } \\ \text { kël[ə]-kël } & \text { Kehle } & \text { 'throat' } \\ \text { sol[ə]-sol } & \text { Sohle } & \text { 'sole' } \\ \text { mül[ə]-mül } & \text { Mühle } & \text { 'mill' } \\ \text { war[ə]-war } & \text { Ware } & \text { 'awareness' }\end{array}$

32. For the development of MHG bir into NHG Birne see n. 47.

33. A counter-example is the feminine noun ûr[ə] 'hour, clock' (NHG Uhr), where the final schwa deleted in a word with a long stem vowel.

34. The assumption that all forms such as those in (38a) are members of a single paradigm can be motivated by the fact that their distribution is determined by agreement with the determiner which functions as the head of the NP. In addition all cases listed there express syntactic relations, a property which distinguishes case from tense - cf. the discussion of the examples in (21).

35. The complete paradigms of these two nouns are given in. The hyphen indicates that the relevant form does not exist. 
(i)

$\begin{array}{rll}\text { SG.NOM } & \text { ruote } & \text { huote } \\ \text { GEN } & \text { ruote(n) } & \text { huote } \\ \text { DAT } & \text { ruote(n) } & \text { huote } \\ \text { ACC } & \text { ruote(n) } & \text { huote } \\ \text { PL.NOM } & \text { ruoten } & - \\ \text { GEN } & \text { ruoten } & - \\ \text { DAT } & \text { ruoten } & - \\ \text { ACC } & \text { ruoten } & -\end{array}$

36. The final schwa failed to delete whenever it functioned as a derivational suffix (e.g. Frisch[ə] 'freshness'-frisch 'fresh', Tief [ə] 'depth'-tief 'deep'), cf. n. 4.

37. This noun is masculine in NHG.

38. Recall that there is no Voice Stability Effect after the cluster $l d$. The schwa loss in the non-count nouns Huld 'grace' from MHG hulde and Schuld from MHG schulde 'responsibility' is therefore systematic.

39. There are numerous counter-examples to the Level Stability Effect among masculine nouns. The patterns of loss indicate that final schwa became reanalysed as a marker encoding the natural gender male in masculine nouns and disappeared whenever it could not be recognized as such. Examples are inanimate nouns like smerz[ə] 'pain' (NHG Schmerz), blitz[a] 'lightning' (NHG Blitz), kîm[ə] 'sprout' (NHG Keim), kern[ə] 'seed' (NHG Kern), stern[ə] 'star' (NHG Stern) but also animate nouns like swan[ə] 'swan' (NHG Schwan), kûz[ə] 'screech owl' (NHG Kauz), spatz[ə] 'sparrow' (NHG Spatz), grîf [ə] 'griffin' (NHG Greif), and mensch[ə] 'human being' (NHG Mensch).

40. This noun stems from Middle Low German.

41. The loss of final schwa in MHG sige 'victory' (NHG Sieg) and grî[z][ə] 'old man' (NHG Greis) are counter-examples to the Voice Stability Effect.

42. Löhken's (1997: 211) claim that schwa loss in the nouns (49a) is explained by their status as function words lacks independent evidence. Regarding phonological structure those nouns conform to the phonological wellformedness conditions for lexical words rather than function words (e.g. they allow for complex syllable heads and/or codas, they resist stem vowel reduction).

43. Glück writes: "Der Vokativ drückt weder syntaktische Beziehungen noch adverbiale Charakterisierungen aus und kann deshalb nicht als Kasus im eigentlichen Sinne gelten.” (p. 683). [The vocative expresses neither syntactic relations nor adverbial characterizations and can therefore not be admitted as a case in the true sense of the word. RR] Cf. also n. 34 .

44. Words which are not subject to Level effects are expected to exhibit the Voice Stability Effect. The only relevant example is the masculine swearword MHG buob[ə] (NHG Bube) 'undisciplined person', which has indeed kept the schwa. 
45. The crucial observation is that inflected word forms often exhibit mismatches between formal and semantic structure. For example, the simplest description of the first singular imperfect subjunctive forms in Latin is that the segment $-m$ is added to the present infinitive active form. While cutting across paradigms on the semantic plane the rule is simple and free of exceptions on the formal plane: however irregular a verb may be in other respects one form always predicts the other (e.g. florere 'to flower' $\rightarrow$ florerem, esse 'to be' $\rightarrow$ essem) (cf. Matthews 1991: 194ff). Similar phenomena abound in natural languages. Such formal identity relations pertaining to fully inflected words cannot be captured in morphological frameworks where semantically complex forms are necessarily derived from simpler forms.

46. The insertion of final $-\mathrm{t}$ in $b \hat{a}[p] s$ and $o[p] 3$ is a later development which is irrelevant for the description of schwa loss.

47. There are two cases of apparent word-final schwa epenthesis in German, both of which are morphologically conditioned. Final schwa was (re)introduced in first person singular present tense verbs by analogical extension (cf. the data in (17a)). Cases of apparent final schwa epenthesis in nouns such as loc >lock[ə] 'curl', trân > trên[ə] 'tear' are due to the reanalysis of former plural forms as singular forms as is shown in (i) (cf. Paul et al. 1989).

(i) Original paradigm Historical reanalysis

New paradigm:

(der) loc $]_{\mathrm{SG}}$

(die) $\operatorname{lock}[\boldsymbol{\partial}]]_{\mathrm{PL}}$

(die) lock[ə] $]_{\mathrm{PL}} \rightarrow(\text { die) lock[ə] }]_{\mathrm{SGFEM}}$

(die) $\operatorname{lock}[\text { ə] }]_{\mathrm{SG}}$

(die) $\operatorname{lock}[ə] \mathrm{n}]_{\mathrm{PL}}$

Reanalysis as in (i) occurred only in nouns which typically occur in groups rather than as individuals. Nouns which were affected by reanalysis accordingly often refer to objects like trees (cf. (iia)), insects (cf. (iib)), small fruits or vegetables (cf. (iic)), or non-unique body parts (cf. (iid)). Nouns ending in a stressed vowel or a liquid preceded by a short vowel could undergo reanalysis twice (e.g. bie 'bee', bir 'pear').

(ii) $\mathrm{MHG}$
a. $\operatorname{asch}>\operatorname{esch}[$ ə] eich $>$ eich[ə]
b. horniz > horniz[ə] bîe $>$ bîn $>$ bîn[ə]
c. bir $>$ birn $>$ birn[ə] arwei3 > arwei3[ə] ber $>$ ber[ə]
d. nier $>$ nier[ə] huft $>$ hüft[ə] druos $>$ drües[ə]
Esche 'ash-tree'
Eiche 'oak'
Hornisse 'hornet'
Biene 'bee'
Birne 'pear'
Erbse 'pea'
Beere 'berry'
Niere 'kidney'
Hüfte 'hips'
Drüse 'gland'

\section{NHG}


The analysis illustrated in (i) is supported by the systematic homophony between the forms which show "schwa epenthesis" and the nominative/accusative plural forms of the original paradigm. Specifically, if the plural in the original paradigm showed umlaut the form with "schwa epenthesis" also has umlaut. In addition, "schwa epenthesis" always correlates with a change to feminine gender, which is apparently conditioned by the homophony between the definite plural article and the definite singular feminine article.

48. The four neuter nouns which are inflected weakly exhibit the Voice Stability Effect:

$\begin{array}{cll}\text { (i) } \text { MHG } & \text { NHG } & \\ \text { hërz[ə] }>\text { hërz } & \text { Herz } & \text { 'heart' } \\ \text { ôr[ə] }>\text { ôr } & \text { Ohr } & \text { 'ear' } \\ \text { oug[ə] } & \text { Auge } & \text { 'eye' } \\ \text { ?(wang[ə] } & \text { Wange } & \text { 'cheek') }\end{array}$

The absence of the LEVEL-Stability Effect in the neuter nouns in (i) is perhaps related to the fact that the paradigms of neuter weak nouns differ from other weak paradigms in that the accusative singular form has no suffix.

49. I assume that the collective neuter nouns discussed in section 2 and the neuter nouns erbe 'inheritance' and ende 'end' lacked plural forms. They accordingly exhibit the Voice Stability Effect.

50. Recall that the Voice Stability Effect always fails after the cluster $l d$. The noun hemde used to be dactylic which means that the loss of final schwa could also have served to satisfy the constraint $\left(\sigma^{2}\right)_{\mathrm{F}}$. There is accordingly no clear evidence that final schwa in either noun deleted to satisfy the constraint $\mathrm{PL} \neq \mathrm{SG}$.

51. The rankings of PRESERVE constraints are feature-specific and are therefore not mentioned in (63).

52. Cf. the discussion in Jeffers and Lehiste (1979: $69 \mathrm{ff})$.

\section{References}

Adelung, J. C.

1781 Deutsche Satzlehre. Zum Gebrauche der Schulen in den Königlich PreuBischen Landen (repr. 1977). Berlin: Hildesheim.

Chomsky, Noam and Morris Halle

1968 The Sound Pattern of English. New York: Harper \& Row.

Drosdowski, Günther

1989 Deutsches Universalwörterbuch. Mannheim: Dudenverlag. Glück, Helmut (ed.)

1993 Metzler Lexikon Sprache. Stuttgart/Weimar: Metzler. 
Hall, T. Alan

1992 Syllable structure and syllable-related processes in German. Tübingen: Niemeyer. (Linguistische Arbeiten 276).

1999 Phonotactics and the prosodic structure of German function words. In T. Allen Hall and Ursula Kleinhenz (eds.), Studies on the Phonological Word. Amsterdam/Philadelphia: John Benjamins.

Heyse, J. C. A.

1838 Dr. J. C. A. Heyses ausführliches Lehrbuch der deutschen Sprache [rev.

K. W. L. Heyse]. Hannover.

Jeffers, Robert J. and Ilse Lehiste

1979 Principles and methods for historical linguistics. MIT Press.

Kiparsky, Paul

1981 Remarks on the metrical structure of the syllable. In W. Dressler, O. E. Pfeiffer and J. R. Rennison (eds.), Phonologica 1980, 245-256. Koziol, Herbert

(Innsbrucker Beiträge zur Sprachwissenschaft). University of Innsbruck.

1937 Der Abfall des nachtonigen -e im Mittelenglischen. Supplement to Anglia 48: 306-309.

Leed, Richard Leaman

1958 A historical Phonology of Czech. Ph.D. dissertation, Cornell University. Lexer, Martin

1876 Mittelhochdeutsches Handwörterbuch. Leipzig: S. Hirzel.

Löhken, Sylvia C.

1997 Deutsche Wortprosodie. Studien zur deutschen Grammatik 56. Stauffenburg Verlag.

Matthews, Peter

1991 Morphology (2nd edition). Cambridge: Cambridge University Press. McCarthy, John and Alan Prince

1986 Prosodic Morphology. Ms. University of Massachusetts and Brandeis University.

Mester, Armin and Junko Itô

1994 Anaptyxis in Optimality Theory: The phonology and morphology of German schwa. Handout, Workshop in prosodic morphology, Utrecht.

Minkova, Donka

1991 The History of Final Vowels in English: The Sound of Muting. Berlin: Mouton de Gruyter.

Olsen, Susan

1991 Ge-Präfigierung im heutigen Deutsch. Beiträge zur Geschichte der deutschen Sprache 113: 333-366.

Paul, Hermann, Peter Wiehl and Siegfried Grosse

1989 Mittelhochdeutsche Grammatik (1st edition 1881). Tübingen: Max Niemeyer Verlag. 
Prince, Alan and Paul Smolensky

1993 Optimality Theory: Constraint interaction in Generative Grammar. Technical Report 2, Center for Cognitive Sciences, Rutgers University, New Brunswick, N.J., and Computer Science Department, University of Colorado, Boulder.

Prokosch, Eduard

1939 A Comparative Germanic Grammar. Pennsylvania: Linguistic Society of America/Philadelphia: University of Pennsylvania.

Raffelsiefen, Renate

1995 Conditions for stability: The case of schwa in German. Theorie des Lexikons. Arbeiten des SFB 282 69. Düsseldorf: Heinrich-Heine Universität.

Riad, Tomas

1992 Structures in Germanic phonology. A diachronic study with special reference to the Nordic languages. Ph.D. dissertation, Stockholm University.

Selkirk, Elisabeth O.

1995 The prosodic structure of function words. University of Massachusetts

Occasional Papers 18: Papers in Optimality Theory, 439-470.

Shibatani, Masayoshi

1973 The role of surface phonetic constraints in generative phonology. Language 49: 87-106.

Sievers, Eduard

1901 Grundzüge der Phonetik. Leipzig: Breitkopf und Härtel.

Smith, Neilson Voyne

1973. The acquisition of phonology. Cambridge: Cambridge University Press. Stampe, David

1969 The acquisition of phonetic representation. Papers from the Fifth Re-

Strauss, Steven gional Meeting of the Chicago Linguistics Society, 443-454.

1982 A Lexicalist Phonology of English and German. Dordrecht: Foris. Vennemann, Theo

1982 Zur Silbenstruktur der deutschen Standardsprache. In Theo Vennemann (ed.), Silben, Segmente, Akzente, 261-305. (Linguistische Arbeiten 126) Tübingen: Niemeyer.

1988 Preference Laws for Syllable Structure and the explanation of sound change. Berlin: Mouton de Gruyter.

Wiese, Richard

1996 The Phonology of German. Oxford: Oxford University Press.

Wilkinson, Karina

1988 Prosodic structure and Lardil phonology. Linguistic Inquiry 19: 325334. 
Wilmanns, W.

1911 Deutsche Grammatik. Volume 1: Lautlehre. Strassburg: Karl J. Trübner. Wurzel, Wolfgang

1970 Studien zur deutschen Lautstruktur. Berlin: Akademie-Verlag. 